\title{
Basic Nickel Carbonate: Part I. Microstructure and Phase Changes during Oxidation and Reduction Processes
}

\author{
M.A. RHAMDHANI, E. JAK, and P.C. HAYES \\ A significant industrial problem associated with the production of nickel from basic nickel \\ carbonate has been identified. Fundamental studies of the change of phase, product surface, and \\ internal microstructures taking place during oxidation and reduction processes at temperatures \\ between $110^{\circ} \mathrm{C}$ and $900{ }^{\circ} \mathrm{C}$ have been carried out. The various elemental reactions and fun- \\ damental phenomena that contribute to the change of the physical and chemical characteristics \\ of the samples during the processes taking place in Ni metal production through gas/solid- \\ reduction processes have been identified and thoroughly investigated. The following phenomena \\ affecting the final-product microstructure were identified as follows: (1) chemical changes, i.e., \\ decomposition, reduction reactions, and oxidation reactions; (2) $\mathrm{NiO}$ and $\mathrm{Ni}$ recrystallization \\ and grain growth; (3) $\mathrm{NiO}$ and $\mathrm{Ni}$ sintering and densification; and (4) agglomeration of the $\mathrm{NiO}$ \\ and Ni particles.
}

DOI: $10.1007 / \mathrm{s} 11663-007-9124-4$

(C) The Minerals, Metals \& Materials Society and ASM International 2008

\section{INTRODUCTION}

THIS article describes a series of fundamental studies to identify the elemental reactions and phenomena taking place during oxidation and reduction processes used in production of solid $\mathrm{Ni}$ metal. A great deal of fundamental research has been undertaken on the factors influencing the gas/solid reduction processes; this includes thermal decomposition reactions and heterogeneous reactions involving gas/solid systems. ${ }^{[1-6]}$ These studies have formed the basis for the use of these reactions in metallurgical and materials production on an industrial scale. The evolution of materials characteristics during these processes is complex, since a number of elemental reactions and fundamental phenomena occur simultaneously; these may include, but are not limited to, solid-precursor decomposition, reduction reactions, oxidation reactions, gas- and solid-phase mass transfer, and sintering. Identifying and describing these fundamental phenomena is important for understanding the underlying science, as well as for improved control of technological applications. Differences in the relative contributions of these phenomena will lead to differences in the properties of the final product.

Despite the accumulated knowledge to date, the complexities of the processes mean that it is still necessary to characterize individual systems through

M.A. RHAMDHANI, formerly Postdoctoral Research Fellow, Pyrometallurgy Research Centre, School of Engineering, University of Queensland, is Lecturer, Faculty of Engineering and Industrial Sciences, Swinburne University of Technology, Hawthorn VIC 3122, Australia. E. JAK, Associate Professor, and P.C. HAYES, Professor, are with the Pyrometallurgy Research Centre, School of Engineering, University of Queensland, Brisbane QLD 4072, Australia. Contact e-mail: ARhamdhani@swin.edu.au

Manuscript submitted October 18, 2007.

Article published online February 14, 2008. systematic experimental studies. An important industrial example of the class of gas/solid-reaction processes is the production of nickel. Basic nickel carbonates $\left(\mathrm{NiCO}_{3} \cdot x \mathrm{H}_{2} \mathrm{O}, \mathrm{NiCO}_{3} \cdot x \mathrm{Ni}(\mathrm{OH})_{2} \cdot y \mathrm{H}_{2} \mathrm{O}, \mathrm{NiCO}_{3} \cdot x \mathrm{NiO} \cdot\right.$ $y \mathrm{H}_{2} \mathrm{O}$ ), or $\mathrm{BNC}$, are used in the commercial production of nickel-metal powders and compacts through calcination and reduction with hydrogen. ${ }^{[7]}$

In the case of nickel production from nickel oxide, residual oxygen and overall reduction rate are the key parameters determining the specification and value of the final $\mathrm{Ni}$ product and the production rates, respectively. The European Union's new chemical policy regulations ${ }^{[8]}$ require that oxygen concentrations in the nickel product are less than $0.1 \mathrm{wt}$ pet as nickel oxide. These restrictions are driven by the need to minimise the generation of residual $\mathrm{NiO}$ dust, which has been shown to be carcinogenic. ${ }^{[9]}$ From the point of view of workplace health and safety, and marketability of nickel products, it is important to characterize the form of any residual nickel oxides present, and to determine how they were formed, and therefore, how they might be further reduced. These processes, as they relate to industrial practice, have not been adequately described in studies to date.

The approach taken in the current study is as follows: (1) systematically investigate the modes of occurrences of residual oxygen (in the form of $\mathrm{NiO}$ ) in the final $\mathrm{Ni}$ product; (2) carry out carefully planned and controlled laboratory experiments to investigate fundamental phenomena and reactions; and (3) relate results from these experiments to microstructures observed in industrial samples to identify fundamental processes occurring during production of $\mathrm{Ni}$ metal through gas/solid reactions.

Figure 1 illustrates the various types of residual $\mathrm{NiO}$ microstructures observed in materials obtained from several locations along the process line in the commercial production of $\mathrm{Ni}$. For the purpose of the following 


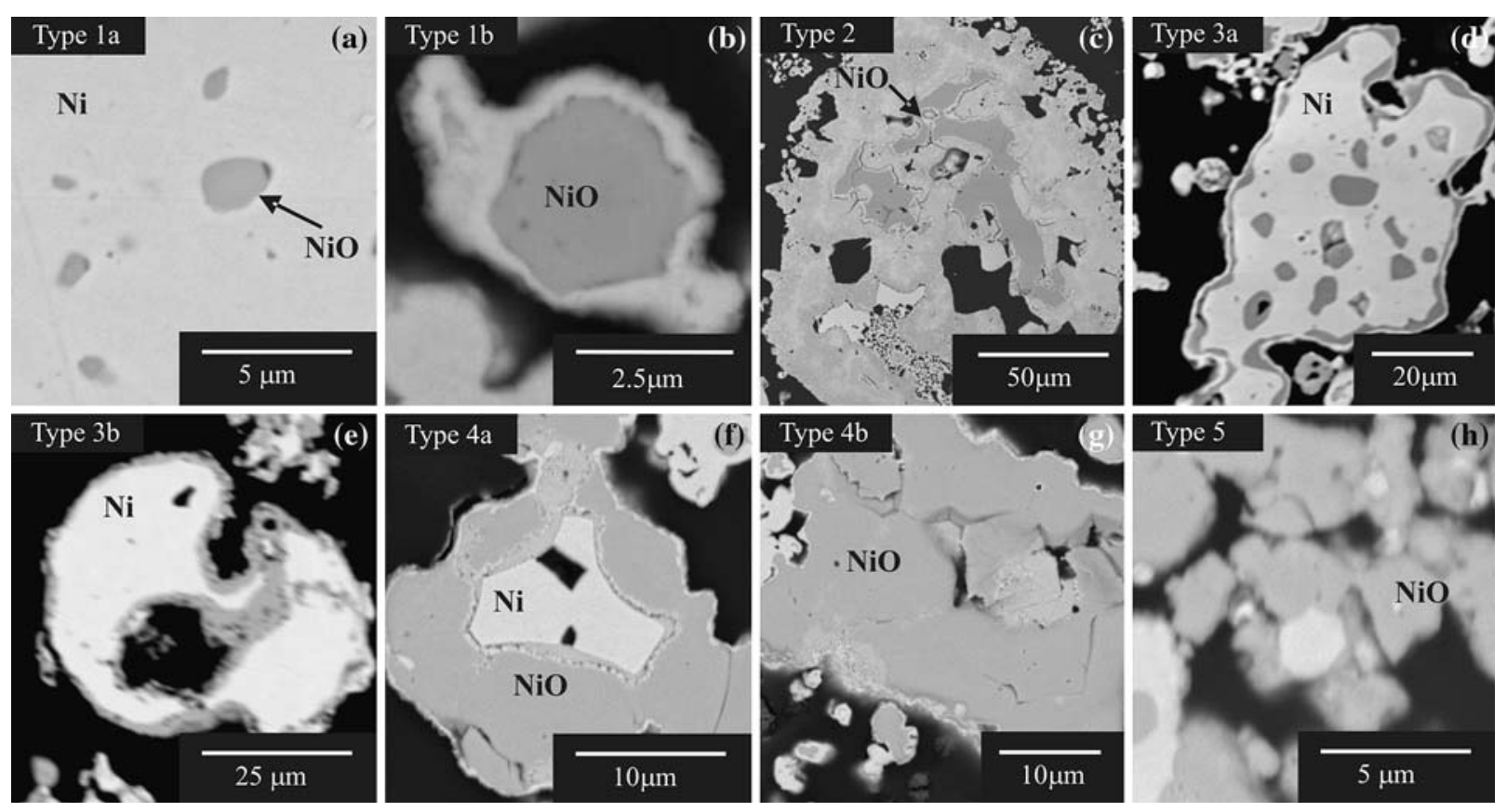

Fig. 1-Examples of types of residual nickel oxides observed in the materials and product of refinery plant: $(a)$ type $1 \mathrm{~A}, \mathrm{NiO}$ enclosed by thick dense $\mathrm{Ni}$; (b) type 1B, NiO enclosed by thin Ni layer; $(c)$ type 2, trapped blocky $\mathrm{NiO}$ surrounded by porous $\mathrm{Ni} ;(d)$ type $3 \mathrm{~A}$, NiO with fine layer of $\mathrm{Ni}$ on $\mathrm{NiO}$ surface; $(e)$ type $3 \mathrm{~B}, \mathrm{NiO}$ on the surface of $\mathrm{Ni}$; $(f)$ type $4 \mathrm{~A}$, bulky $\mathrm{NiO}$ with dense $\mathrm{Ni}$ inside; $(g)$ type $4 \mathrm{~B}$, bulky $\mathrm{NiO}$; and $(h)$ type 5 , fine partially reduced $\mathrm{NiO}$ particles, size 1 to $5 \mu \mathrm{m}$.

systematic investigation of the processes resulting in formation of these various types of $\mathrm{NiO}$, these have been classified as follows:

(1) type 1-trapped round particles surrounded by (1A) thick or (1B) thin dense $\mathrm{Ni}$;

(2) type 2-trapped blocky form surrounded by porous $\mathrm{Ni}$;

(3) type 3-surface layer of a $\mathrm{NiO}$ on a $\mathrm{Ni}$ particle (3A) with or (3B) without a fine layer of $\mathrm{Ni}$ on oxide surface;

(4) type 4-bulky $\mathrm{NiO}$ (4A) with or (4B) without dense Ni inside; and

(5) type 5-fine partially reduced $\mathrm{NiO}$ particles with individual particle size of one to five $\mu \mathrm{m}$.

From Figure 1, it clearly follows that residual $\mathrm{NiO}$ is present in various complex structures, which resulted from different phenomena occurring during the $\mathrm{Ni}$ production process. Understanding of the phenomena resulting in the formation of these residual, nickel-oxide microstructures is important for the process control to obtain a high-quality nickel product.

In Part I of the series, a systematic investigation of changes in phases present, product surface, and internal microstructures occurring in starting material $\mathrm{BNC}$ during controlled oxidation and reduction conditions is provided. The principal aim of the study is to identify the various fundamental phenomena occurring and their effects on the processes and the final product. This is to provide a basis for future fundamental studies on each of the phenomena and also provide information in support of industrial operations. In Part II of the series, the analysis of the microstructure formation in intermediate and final products during industrial operations and the implications for plant practices are described.

\section{PREVIOUS STUDIES ON BNC DECOMPOSITION AND NiO REDUCTION}

There have been a number of studies on the thermal decomposition of $\mathrm{BNC}$ and nickel carbonates using thermo-gravimetric analysis (TGA) and differential thermal analysis (DTA) ${ }^{[10-14]}$ It is generally agreed that the thermal decomposition of various $\mathrm{BNC}$ proceeds in two steps, first involving the removal of $\mathrm{H}_{2} \mathrm{O}$ only, and then $\mathrm{H}_{2} \mathrm{O}$ and $\mathrm{CO}_{2}$. Using heating rates between $2{ }^{\circ} \mathrm{C} /$ min to $50{ }^{\circ} \mathrm{C} / \mathrm{min}$ the evolution of $\mathrm{H}_{2} \mathrm{O}$ only is reported to occur from $90{ }^{\circ} \mathrm{C}$ to $200{ }^{\circ} \mathrm{C}$; the evolution of $\mathrm{H}_{2} \mathrm{O}$ and $\mathrm{CO}_{2}$ occurs from $270{ }^{\circ} \mathrm{C}$ to $420{ }^{\circ} \mathrm{C}$. The two steps of decomposition of $\mathrm{BNC}$ can be represented by the following chemical reactions:

$x \mathrm{NiCO}_{3} \cdot y \mathrm{Ni}(\mathrm{OH})_{2} \cdot z \mathrm{H}_{2} \mathrm{O} \rightarrow x \mathrm{NiCO}_{3} \cdot y \mathrm{Ni}(\mathrm{OH})_{2}+z \mathrm{H}_{2} \mathrm{O}$

$$
x \mathrm{NiCO}_{3} \cdot y \mathrm{Ni}(\mathrm{OH})_{2} \rightarrow(x+y) \mathrm{NiO}+x \mathrm{CO}_{2}+y \mathrm{H}_{2} \mathrm{O}
$$

The two decomposition steps are reported to apply to $2 \mathrm{NiCO}_{3} \cdot 3 \mathrm{Ni}(\mathrm{OH})_{2} \cdot 4 \mathrm{H}_{2} \mathrm{O},{ }^{[11,13]} \mathrm{NiCO}_{3} \cdot 2 \mathrm{Ni}(\mathrm{OH})_{2} \cdot 4 \mathrm{H}_{2} \mathrm{O},{ }^{[12]}$ and $\mathrm{NiCO}_{3} \cdot \mathrm{Ni}(\mathrm{OH})_{2} \cdot 2 \mathrm{H}_{2} \mathrm{O} \cdot{ }^{[14]}$ Only in the latter study ${ }^{[14]}$ have the microstructure changes occurring during the transformation from $\mathrm{BNC}$ to $\mathrm{NiO}$ particles been 
examined; however, this is a very cursory study of these phenomena.

There have been a number of studies on the gaseous reduction of nickel oxide to nickel by hydrogen-based gases, ${ }^{[15-21]}$ in which the overall reaction can be expressed as follows:

$$
\mathrm{NiO}_{(s)}+\mathrm{H}_{2(g)} \rightarrow \mathrm{Ni}_{(s)}+\mathrm{H}_{2} \mathrm{O}_{(g)}
$$

In many cases, the starting point for these studies involved the use of finely divided $\mathrm{NiO}$ powder or compacts. Although reduction in hydrogen atmospheres was found by many investigators to occur readily, there are considerable differences in the reported kinetics of these processes due to the differing characteristics of the starting materials and the reaction geometries employed in these studies. ${ }^{[15-21]}$ In relatively few studies, the reaction conditions have been well established, using either dense $\mathrm{NiO}$ sheets ${ }^{[16-18]}$ or granules ${ }^{[20,21]}$ to overcome gas-phase mass-transfer limitations. These studies show that the reaction rates increase with increasing temperatures up to $600{ }^{\circ} \mathrm{C}$, and then a slowdown between $600{ }^{\circ} \mathrm{C}$ to $900{ }^{\circ} \mathrm{C}$, before increasing again above $950{ }^{\circ} \mathrm{C}$. There are no phase changes taking place in this range of temperatures, and no physical changes to the oxide or metallic phases were detected that might explain the slowdown of the reaction between $600{ }^{\circ} \mathrm{C}$ to $900{ }^{\circ} \mathrm{C}$. A number of mechanisms have been proposed to explain the observed reduction behavior, but to date, the origins of these phenomena remain uncertain.

The majority of the studies on BNC are focused on the thermal decomposition in air and limited to low temperatures $\left(<600{ }^{\circ} \mathrm{C}\right)$. On the other hand, although research has been carried out on $\mathrm{NiO}$ reduction at temperature ranges between $200{ }^{\circ} \mathrm{C}$ to $1000{ }^{\circ} \mathrm{C}$, there are no published studies of microstructure evolution during reduction of $\mathrm{BNC}$ to $\mathrm{NiO}$, and then to $\mathrm{Ni}$.

Although the gaseous transformation of $\mathrm{BNC}$ to $\mathrm{NiO}$, and then reduction to nickel by hydrogen appear to be simple reactions, the factors influencing the extent and rates of reduction, and its inter-relationship with the microstructure are not completely under- stood. The reduction of $\mathrm{BNC}$ and $\mathrm{NiO}$ appear to be strongly dependent on the characteristics of the starting materials, the process conditions, and thermal history. This is of particular concern for the accurate control of industrial processes used in the production of nickel oxide and nickel metal powders, in which variations in product quality and characteristics are undesirable.

\section{EXPERIMENTAL DESIGN}

\section{A. Materials}

In the current study, BNC supplied by the BHP Billiton Yabulu Refinery was used as the starting material. The BNC was produced by precipitation of nickel from an ammonia-ammonium carbonate solution. The particles were spherical and ellipsoidal in shape, as shown in Figure 2, ranging from 0.4 to $23 \mu \mathrm{m}$ in diameter, with a mean diameter of $8.2 \mu \mathrm{m}$. The surfaces of the particles were superficially smooth; the BrunauerEmmett-Teller (BET)-specific surface area of the original BNC particles was $238 \mathrm{~m}^{2} / \mathrm{g}$. Prior to experiments, BNC samples were dried in an oven in air atmosphere at a temperature of $105^{\circ} \mathrm{C}$ for 16 hours to release the physically bound $\mathrm{H}_{2} \mathrm{O}$. The dried $\mathrm{BNC}$ contained approximately 52 pet wt $\mathrm{Ni}, 3.52$ pet wt $\mathrm{C}$, and approximately 0.001 pct wt $\mathrm{S}$; the balance was predominantly $\mathrm{O}$ and $\mathrm{H}_{2} \mathrm{O}$. On this basis, the calculated composition is approximately $\mathrm{NiCO}_{3} \cdot 2.02 \mathrm{Ni}(\mathrm{OH})_{2} \cdot 1.94 \mathrm{H}_{2} \mathrm{O}$.

\section{B. Experimental Plan}

The experimental plan in the current study was developed following careful evaluation of the modes of occurrences of residual nickel oxide in the materials (Figure 1), the thermal and atmosphere conditions in the actual process, and consideration of possible elementary reactions and phenomena involved in the gas/solid reaction processes.

Separate and combination heat treatments on $\mathrm{BNC}$ samples under specific experimental conditions were
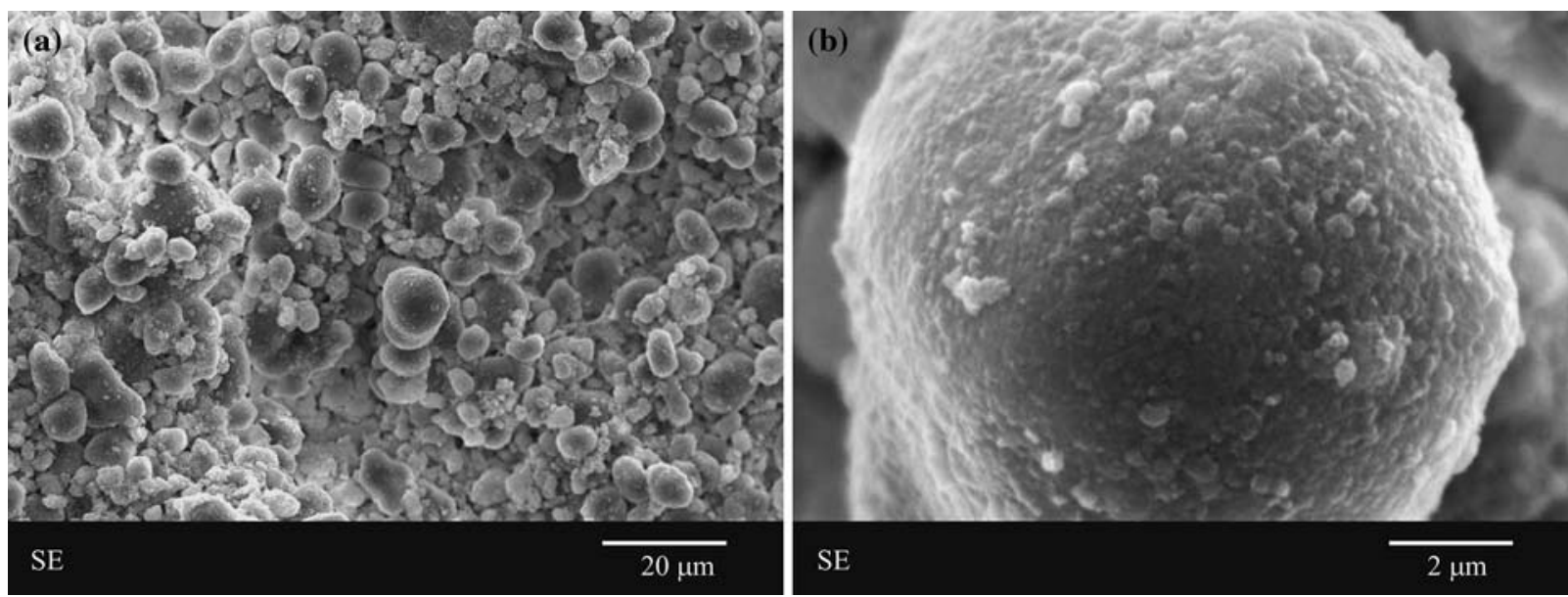

Fig. 2-SEM micrographs (secondary electron images) showing the surface morphology of the original BNC particles. Note the smooth surface of the particles, which consist of submicron grains. 
carried out to reproduce some of the residual nickeloxide microstructures to allow the investigation of the underlying elementary reactions and fundamental phenomena occurring during the process responsible for the formation of these microstructures.

The heat treatments carried out in this study are as follows: (1) calcination/oxidation of BNC in air; (2) direct reduction of $\mathrm{BNC}$ in reducing (15 pct $\mathrm{H}_{2}-\mathrm{N}_{2}$ and $1.5 \mathrm{pct}$ $\mathrm{H}_{2}-\mathrm{N}_{2}$ ) gas atmosphere; and (3) reduction in 15 pct $\mathrm{H}_{2-}$ $\mathrm{N}_{2}$ gas atmosphere of preoxidized/calcined BNC.

The calcination/oxidation and reduction of the samples were carried out at temperatures between $110{ }^{\circ} \mathrm{C}$ and $900{ }^{\circ} \mathrm{C}$. The samples were held at the peak temperatures for 30,60 , and 120 minutes to evaluate the effect of holding time at a temperature. The heating rate of $10{ }^{\circ} \mathrm{C} / \mathrm{min}$ used in the study was selected to reflect the heating rate in the rotary kiln used in industrial production of nickel. ${ }^{[22]}$

\section{Experimental Technique}

The oxidations and reductions were carried out in an electrically heated furnace inside a quartz tube, using a top-blown fluidising particle technique. The schematic of the furnace used in the current study is shown in Figure 3. The reducing/oxidizing gases were introduced through a 5-mm-inner diameter (ID) alumina injection tube from the top, blowing and circulating the particles at the bottom of the closed-end, 30-mm-diameter quartz tube. The flow rates utilized in the experiments were 500 to $1000 \mathrm{~mL} / \mathrm{min}$. The quartz tube was supported by a steel frame separate from the furnace, and it was moveable. A mechanical vibrator was attached to the steel frame, thus indirectly vibrating the quartz tube; this ensured that a good circulation of the particles in the sample bed was maintained throughout the experiments and enhanced the contact between the gas and the particles.

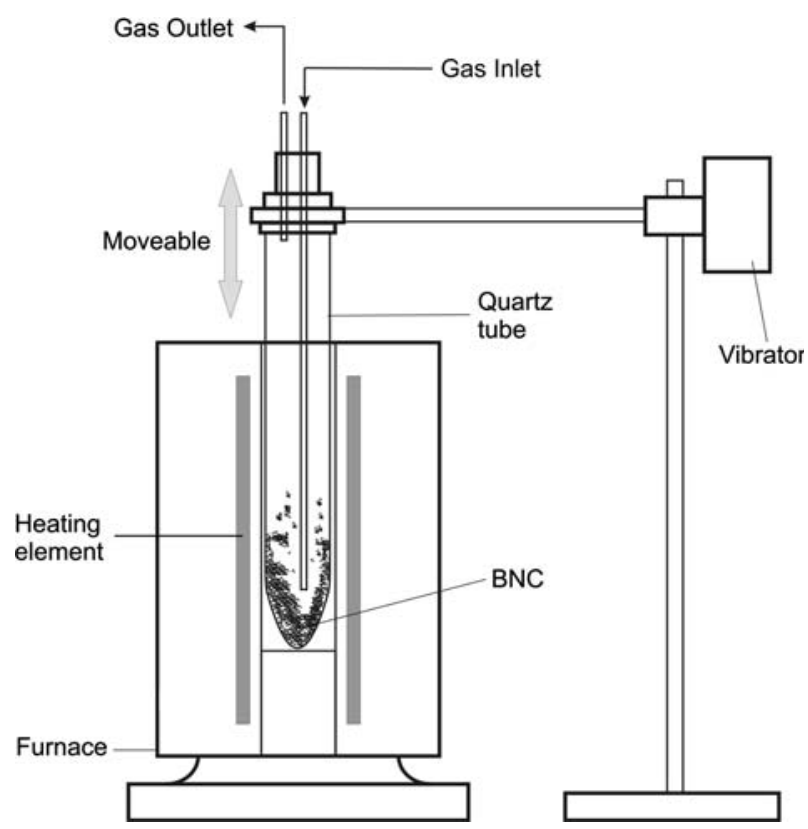

Fig. 3-Schematic of the experimental apparatus used to treat BNC powders.
Approximately $5 \mathrm{~g}$ of sample were initially placed in the quartz tube. The samples were heated to the desired temperature in the desired atmosphere. After reaching the desired temperature, the samples were held at the temperature before they were quickly cooled by removing the quartz tube from the furnace and by passing a flow of inert gas $\left(\mathrm{Ar}\right.$ or $\left.\mathrm{N}_{2}\right)$ through the system. The samples were then analyzed using materials-characterization techniques to study the phase changes and microstructure/surface-morphology evolution during the process. Selected repeated experiments were carried out to ensure the consistency and repeatability of the experiments.

\section{Analysis Techniques and Sample Preparation}

The microstructures of the samples were examined using scanning electron microscopy (SEM) and energy dispersive X-ray (EDX) techniques, namely, FE-SEM JEOL* 6300/6400, variable pressure SEM

*JEOL is a trademark of Japan Electron Optics Ltd., Tokyo.

JEOL 6460LA, and PHILIPS** XL-30 with acceler-

**PHILIPS is a trademark of FEI Company, Hillsboro, OR.

ating voltage of 15 and $20 \mathrm{kV}$. X-ray powder diffraction (XRD) analyses were carried out using PHILIPS PW 1130 X-ray diffractometer with a graphite monochromator using $\mathrm{Cu} K_{\alpha}$ radiation.

Thermo-gravimetric analysis and DTA were carried out on the samples using the STA 409C/CD (NETZSCH GmbH, Bayern, Germany). Specific surface-area measurement of selected samples was carried out using the Tristar 3000 (Micromeritics Instrument Corp., Norcross, GA). Particle-size measurement of the samples was carried out using the Mastersizer 2000 (Malvern Instruments Ltd., Worchestershire, United Kingdom).

To enable the examination of the internal microstructures of the materials, the samples, after the experiments, were mounted in epoxy resin and cured in a vacuum chamber. Cross sections of the samples were then prepared by polishing, using $\mathrm{SiC}$ paper and diamond paste (down to a $0.25 \mu \mathrm{m}$ size). For SEM surface-morphology observations, the powder samples after the experiments were directly placed on a carbon tab attached to an aluminium pin stub before being sputter coated using an Eiko IB-5 Sputter Coater (Eiko Co. Ltd., Hitachinaka, Japan) with platinum.

\section{RESULTS AND DISCUSSION}

\section{A. BNC Samples Calcined in Air}

The behavior, fundamental reactions, and microstructural changes of $\mathrm{BNC}$ during calcination in air were 


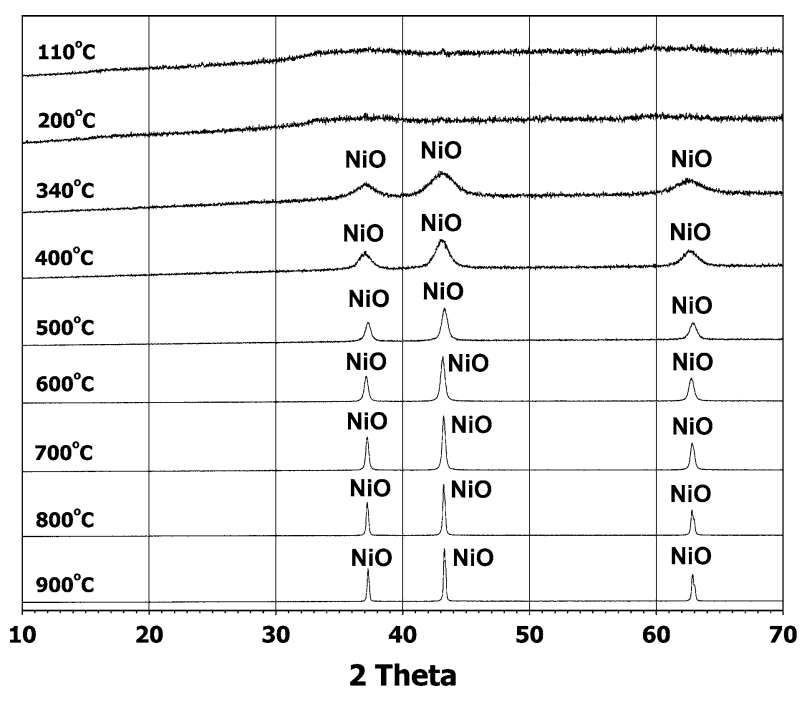

Fig. 4-XRD spectra of BNC samples calcined in air at various temperatures. Heating rate $10^{\circ} \mathrm{C} / \mathrm{min}$, holding time at temperature $30 \mathrm{~min}, \mathrm{Cu} K_{\alpha}$ radiation used.

characterized using a number of techniques. Figure 4 shows the XRD patterns of BNC samples calcined in air for 30 minutes at various temperatures. The XRD analyses of the samples heated at $110^{\circ} \mathrm{C}$ and $200{ }^{\circ} \mathrm{C}$ show no clear $\mathrm{X}$-ray diffraction peaks, suggesting that the material was in an amorphous or microcrystalline state. At $340{ }^{\circ} \mathrm{C}$, it can be seen that the $\mathrm{NiO}$ diffraction peaks appear, indicating that the reaction in Figure 2 had already commenced. As the temperature of calcination is increased to $900{ }^{\circ} \mathrm{C}$, the $\mathrm{NiO}$ peaks become sharper.

From the XRD results, the average crystallite size of the $\mathrm{NiO}$ was estimated by using the Debye-Scherrer formula, ${ }^{[23]}$ i.e., calculated from the broadening of the $\mathrm{X}$-ray peaks at half maximum, as follows:

$$
D=0.89 \lambda / \beta \cos \theta
$$

where $D$ is the average crystallite size, $\lambda$ is the $\mathrm{Cu} K_{\alpha}$ wavelength (1.5418 $\AA$ ), and $\beta$ is the peak width at half maximum. Assuming a zero contribution from strain, the values of $\beta$ were corrected by considering the broadening due to instrumental effects. ${ }^{[23]}$ The instrumental effects to the X-ray peaks broadening were determined by analysing NIST $640 \mathrm{C}$ silicon standard and were found to have a value of $\beta_{\text {inst }}=0.134 \mathrm{deg}$. Table I shows the summary of the effect of maximum calcination temperature in air on the average $\mathrm{NiO}$ crystallite size. At $340{ }^{\circ} \mathrm{C}$, the average crystallite size

Table I. Effect of Maximum Calcination Temperature in Air on the Average NiO Crystallite Size, Calculated Using Debye-Scherrer Formula (BNC Heating Rate $10{ }^{\circ} \mathrm{C} / \mathrm{min}$; Holding Time at Temperature 30 Minutes)

\begin{tabular}{lrrrrrrr}
\hline $\begin{array}{l}\text { Temperature } \\
\text { of calcination }\left({ }^{\circ} \mathrm{C}\right)\end{array}$ & 340 & 400 & 500 & 600 & 700 & 800 & 900 \\
$\begin{array}{c}\text { Average crystallite } \\
\text { size, } D(\mathrm{~nm})\end{array}$ & 4 & 7 & 16 & 24 & 34 & 44 & 52 \\
\hline
\end{tabular}

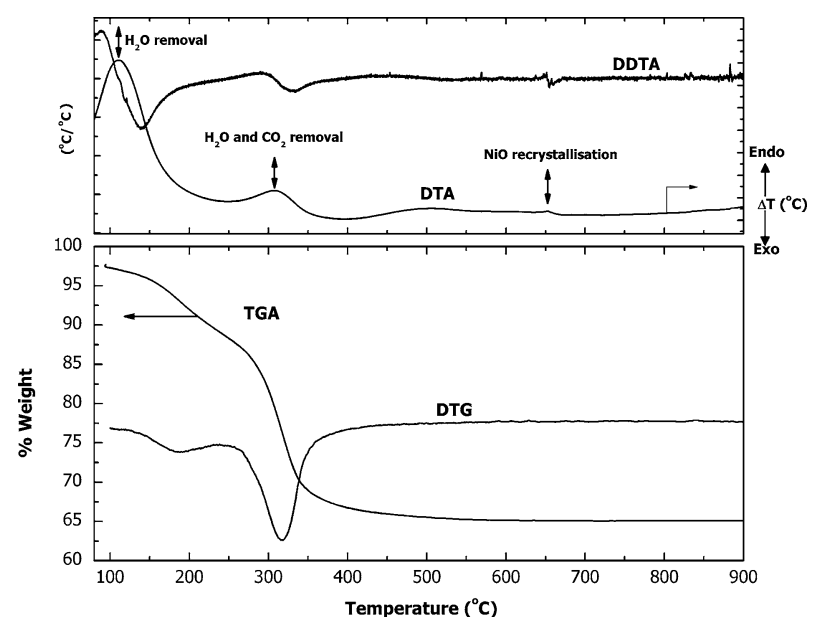

Fig. 5-DTA, TGA, DTG, and DDTA curves of BNC samples heated in air with heating rate of $10^{\circ} \mathrm{C} / \mathrm{min}$.

was appromixately $4 \mathrm{~nm}$; the average crystallite size increases with increasing calcination temperatures. At $900{ }^{\circ} \mathrm{C}$, the calculated average crystallite size was approximately $52 \mathrm{~nm}(0.052 \mu \mathrm{m})$, and this value is comparable to the size of $\mathrm{NiO}$ grains observed using SEM, as demonstrated subsequently in this article.

Figure 5 shows the TGA and DTA results of BNC heated in air from room temperature to $900{ }^{\circ} \mathrm{C}$, with a heating rate of $10^{\circ} \mathrm{C} / \mathrm{min}$. The DTA curve shows two maxima at $110^{\circ} \mathrm{C}$ and $310^{\circ} \mathrm{C}$, and the differential thermal gravimetry (DTG) curve suggests that the first decomposition of BNC occurred between $100{ }^{\circ} \mathrm{C}$ and $220^{\circ} \mathrm{C}$, and that the second decomposition occurred in the range of $230{ }^{\circ} \mathrm{C}$ to $370{ }^{\circ} \mathrm{C}$. These may be attributed to the release of $\mathrm{H}_{2} \mathrm{O}$ and the formation of nickel oxide (second removal of $\mathrm{H}_{2} \mathrm{O}$ and $\mathrm{CO}_{2}$ ), respectively, as has been suggested by previous investigators. ${ }^{[10-14]}$ These observations and interpretations are supported by the $\mathrm{XRD}$ results that indicate that at $340{ }^{\circ} \mathrm{C}$, nickel oxide had already formed.

Figures 6(a) through (h) represent selected SEM micrographs of the surface morphologies and the sectioned microstructures of $\mathrm{BNC}$ samples at various temperatures, following treatment in air. At $110^{\circ} \mathrm{C}$ to $200{ }^{\circ} \mathrm{C}$, the shapes and the sizes of the particles were still the same as in the original particles. Figures 6(a) and (b) show SEM images of the surface and internal microstructure of a BNC particle at $200{ }^{\circ} \mathrm{C}$. In general, discrete particles were observed at that temperature, rather than agglomerates. In Figure 6(b), the particles appear uniform in cross section; however, on heating above $200{ }^{\circ} \mathrm{C}$, a concentric layer structure can be seen in some of the particles.

The concentric layer structure became more distinct upon heating up to $400{ }^{\circ} \mathrm{C}$ and $600{ }^{\circ} \mathrm{C}$ (Figure $6(\mathrm{~d})$ ). Some of the larger particles consist of two or more concentric layer structure cores, indicating the successive formation of layers on the particles' surfaces during the precipitation reaction.

At $700{ }^{\circ} \mathrm{C}$ and $800{ }^{\circ} \mathrm{C}$, there were signs that agglomeration had occurred during calcination; agglomerates in the range of 50 to more than $100 \mu \mathrm{m}$ were observed at 

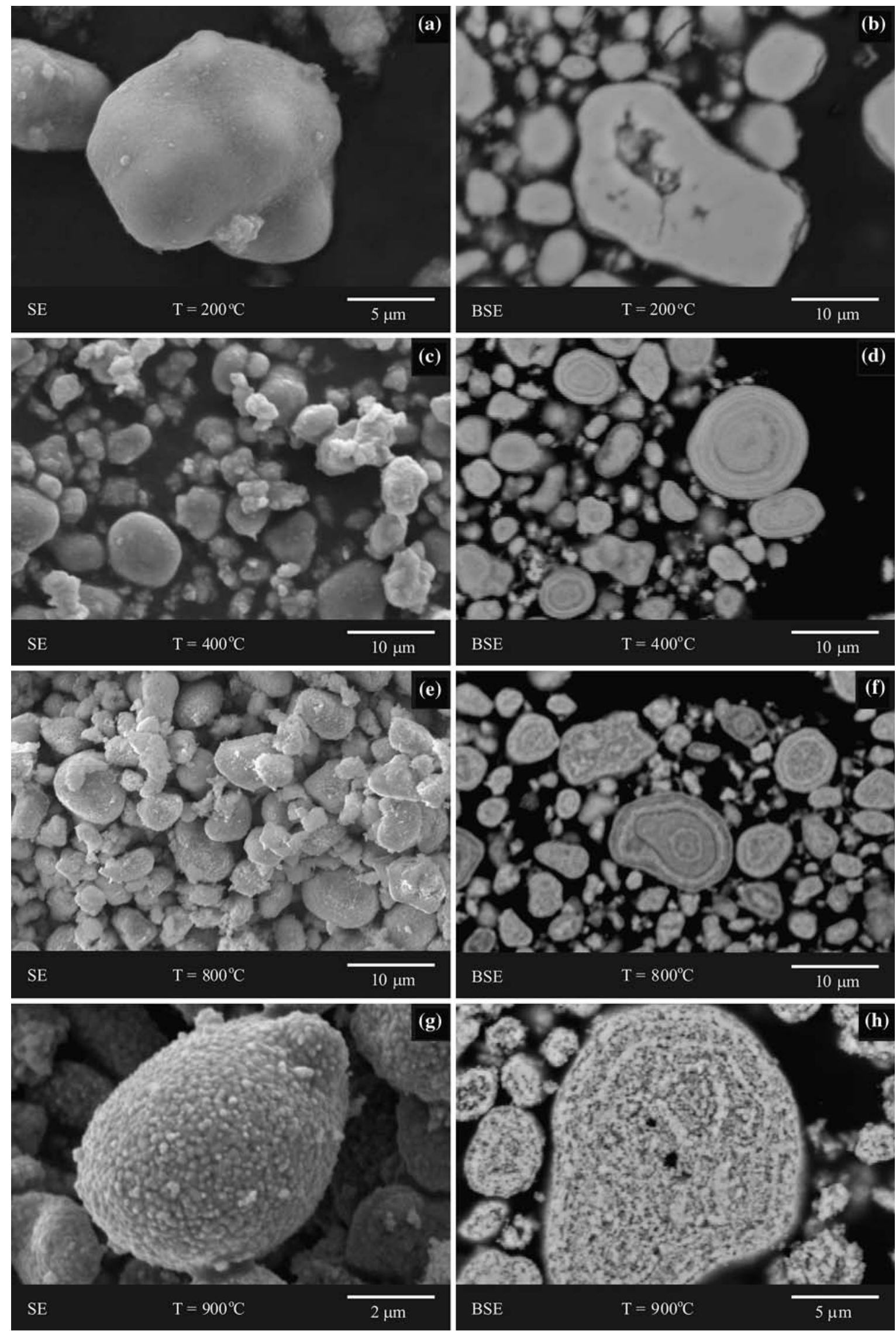

Fig. 6-SEM micrographs of the surface (left column) and the cross sections (right column) of $\mathrm{BNC}$ samples calcined in air $\left(30 \mathrm{~min}, 10{ }^{\circ} \mathrm{C} / \mathrm{min}\right.$ heating rate) at various temperatures: $(a)$ and $(b) 200{ }^{\circ} \mathrm{C} ;(c)$ and $(d) 400{ }^{\circ} \mathrm{C} ;(e)$ and $(f) 800{ }^{\circ} \mathrm{C}$; and $(g)$ and $(h) 900{ }^{\circ} \mathrm{C}$. 
$800{ }^{\circ} \mathrm{C}$. In some particles, a clear, physical separation between layers in the concentric layer structure had occurred by $800{ }^{\circ} \mathrm{C}$. At temperatures in the range of $800{ }^{\circ} \mathrm{C}$ to $900{ }^{\circ} \mathrm{C}$, random distributions of a very small $(<0.1 \mu \mathrm{m})$ recrystallized $\mathrm{NiO}$ grains were observed throughout the particles, destroying the concentric layer structure.

Referring to the results in Figure 5, it can be suggested from a small DTA peak at $660{ }^{\circ} \mathrm{C}$ that the recrystallization of $\mathrm{NiO}$ occurred at that temperature. This peak can be clearly seen in the first derivative of differential thermal analysis (DDTA) curve. The newly recrystallized $\mathrm{NiO}$ grains were, however, indistinguishable at $700{ }^{\circ} \mathrm{C}$ and $800{ }^{\circ} \mathrm{C}$, which was likely due to the very small size of the grains. From the XRD peaks in Figure 4, the calculated average crystallite sizes at $700{ }^{\circ} \mathrm{C}$ and $800{ }^{\circ} \mathrm{C}$ were 34 and $44 \mathrm{~nm}$, respectively. Figures $6(\mathrm{~g})$ through (h) show SEM images of the surface and sectioned particles at $900{ }^{\circ} \mathrm{C}$. It can be clearly seen from Figure 6(h) that submicron grains, having diameter of approximately 0.05 to $0.1 \mu \mathrm{m}$, are observed on the surface and within the particle. This is consistent with the average crystallite size calculated using the Debye-Scherrer formula $(0.052 \mu \mathrm{m})$.

\section{B. BNC Sample Reduced in 15 Pct $\mathrm{H}_{2}-\mathrm{N}_{2}$ Gas Atmosphere}

To study the behavior, fundamental reactions and microstructure change of $\mathrm{BNC}$ in reducing conditions, $\mathrm{BNC}$ samples were again heated to various temperatures using a $10^{\circ} \mathrm{C} / \mathrm{min}$ heating rate, but in this series of experiments, a 15 pct $\mathrm{H}_{2}-\mathrm{N}_{2}$ gas atmosphere was used.

Figure 7 shows the XRD analyses of the samples reduced in 15 pct $\mathrm{H}_{2}-\mathrm{N}_{2}$ at different temperatures. It can be seen that at $100{ }^{\circ} \mathrm{C}$ to $200{ }^{\circ} \mathrm{C}$, no peaks are observed, indicating the samples were in an X-ray amorphous state. At $340{ }^{\circ} \mathrm{C}$, broad $\mathrm{NiO}$ X-ray diffraction peaks

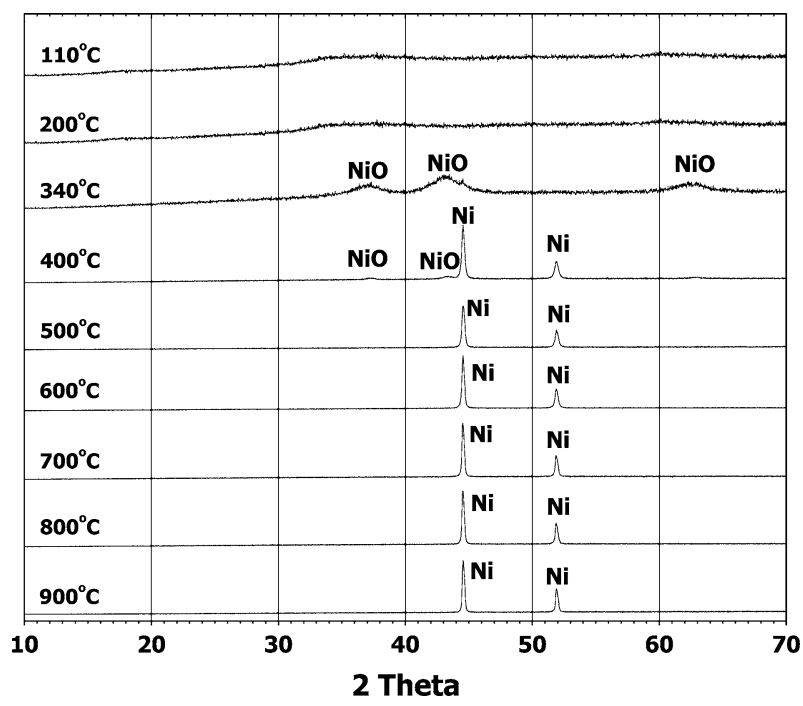

Fig. 7-XRD spectra of BNC sample reduced in 15 pct $\mathrm{H}_{2}-\mathrm{N}_{2}$ at various temperatures. Heating rate $10{ }^{\circ} \mathrm{C} / \mathrm{min}$, holding time at temperature 30 minutes, $\mathrm{Cu} K_{\alpha}$ radiation used. are observed, which indicate the formation of a fine-crystalline oxide. A small Ni-metal peak is also observed at this temperature. These suggest that upon heating in a reducing atmosphere, $\mathrm{BNC}$ first decomposes to nickel oxide, before forming nickel nuclei. At $400{ }^{\circ} \mathrm{C}$, the X-ray diffraction pattern consists principally of $\mathrm{Ni}$ with residual $\mathrm{NiO}$. Upon increasing the temperature to $900{ }^{\circ} \mathrm{C}$, the $\mathrm{Ni} \mathrm{X}$-ray diffraction peaks become sharper.

At $100{ }^{\circ} \mathrm{C}$ to $200{ }^{\circ} \mathrm{C}$, the surface morphology of the particles was similar to $\mathrm{BNC}$ particles oxidized at $110^{\circ} \mathrm{C}$ to $200^{\circ} \mathrm{C}$ in air. The majority of the 1 - to 10 $\mu \mathrm{m}$ particles were spherical or ellipsoidal in shape, having smooth external surfaces. The sectioned microstructure of $\mathrm{BNC}$ particles at $200{ }^{\circ} \mathrm{C}$ appeared to be uniform, with concentric layer structure observed in some of the particles.

Figures 8(a) and (b) show SEM images of the surface and microstructure of sectioned particles at $340{ }^{\circ} \mathrm{C}$. From the cross-sectional observation, it can be seen that at this temperature, some of the particles had transformed to more porous/spongy particles (Ni particles). The concentric layer structure of the particles at this temperature was quite distinct. Agglomeration of some of the Ni particles was observed at $340{ }^{\circ} \mathrm{C}$.

The SEM observations of the particles treated at $400{ }^{\circ} \mathrm{C}$ to $500{ }^{\circ} \mathrm{C}$ showed that the surfaces of most particles were covered with porous/spongy $\mathrm{Ni}$ and that extensive agglomeration of the particles had occurred. The size of the agglomerates can be more than $100 \mu \mathrm{m}$. By $500{ }^{\circ} \mathrm{C}$, it appears that all of the particles had transformed to porous $\mathrm{Ni}$ crystals, confirming the XRD results.

At $700{ }^{\circ} \mathrm{C}$, the spongy nickel particles consisted of 0.05 - to $0.1-\mu \mathrm{m}$-diameter nickel grains (Figures 8 (c) and (d). At $800^{\circ} \mathrm{C}$, grain growth of the subgrains had occurred, such that the mean grain size of the nickel was of the order $1 \mu \mathrm{m}$. Extensive agglomeration of the particles at $800{ }^{\circ} \mathrm{C}$ can be seen in Figures 8(e) and (f).

At $900{ }^{\circ} \mathrm{C}$, the particles had formed agglomerates/ lumps of more than $700 \mu \mathrm{m}$ in diameter. The Ni grains had coarsened to more than $1 \mu \mathrm{m}$ in size. There was clear evidence of sintering and densification of the $\mathrm{Ni}$ structure (Figures $8(\mathrm{~g})$ and $(\mathrm{h})$ ). From the particle cross sections, there was no evidence of residual nickel-oxide trapped inside the dense nickel; the darker regions at the center of the particles in Figure 8(h) are isolated pores.

Additional experiments were carried out using longer reduction times at the peak temperatures, i.e., 60 and 120 minutes. Above $700{ }^{\circ} \mathrm{C}$, there was a significant sintering/densification of the nickel when the reduction time was increased to 60 or 120 minutes (Figure 9).

The X-ray powder diffraction results and SEM observation were related to the DTA and TGA results. Figure 10 is an example of the DTA and TGA results; in this case, the reduction of $\mathrm{BNC}$ was carried out in 5 pct $\mathrm{H}_{2}-\mathrm{N}_{2}$ (rather than in 15 pct $\mathrm{H}_{2}-\mathrm{N}_{2}$ ) with a heating rate of $10^{\circ} \mathrm{C} / \mathrm{min}$. This atmosphere condition was selected after considering the constraint of the instrument in using high hydrogen content gases and the safety assessment associated with the experimental procedure. However, it was expected that this would resemble the case of reduction in 15 pet $\mathrm{H}_{2}-\mathrm{N}_{2}$. From the DTA and DTG curves, it could 

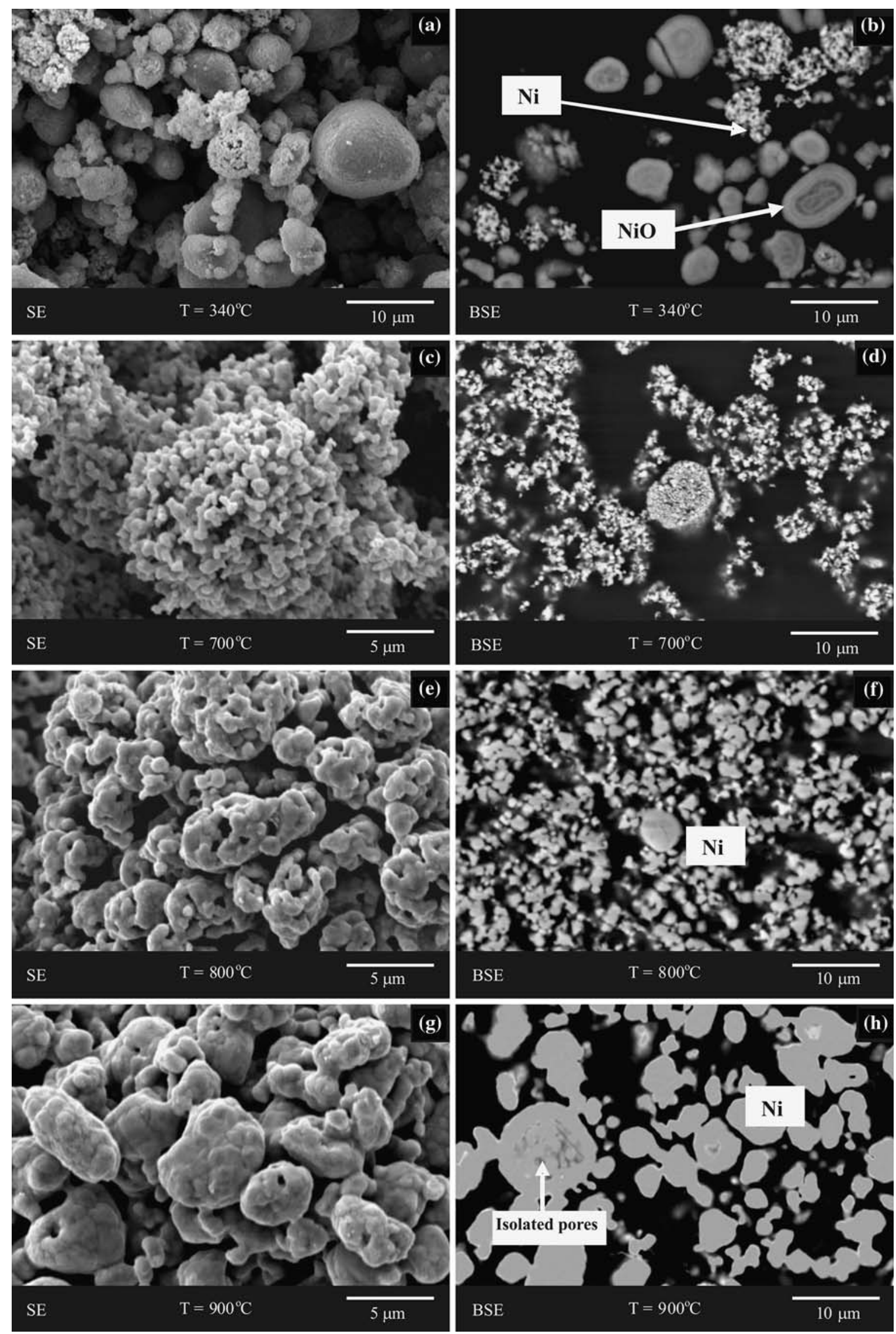

Fig. 8- SEM micrographs of the surface (left column) and the sections (right column) of BNC sample reduced in 15 pct $\mathrm{H}_{2}-\mathrm{N}_{2}\left(30 \mathrm{~min}, 10^{\circ} \mathrm{C} / \mathrm{min}\right.$ heating rate) at various temperatures: $(a)$ and $(b) 340{ }^{\circ} \mathrm{C},(c)$ and $(d) 700{ }^{\circ} \mathrm{C},(e)$ and $(f) 800{ }^{\circ} \mathrm{C}$, and $(g)$ and $(h) 900{ }^{\circ} \mathrm{C}$. Nickel metal appears as the bright phase in $(\mathrm{b})$. 

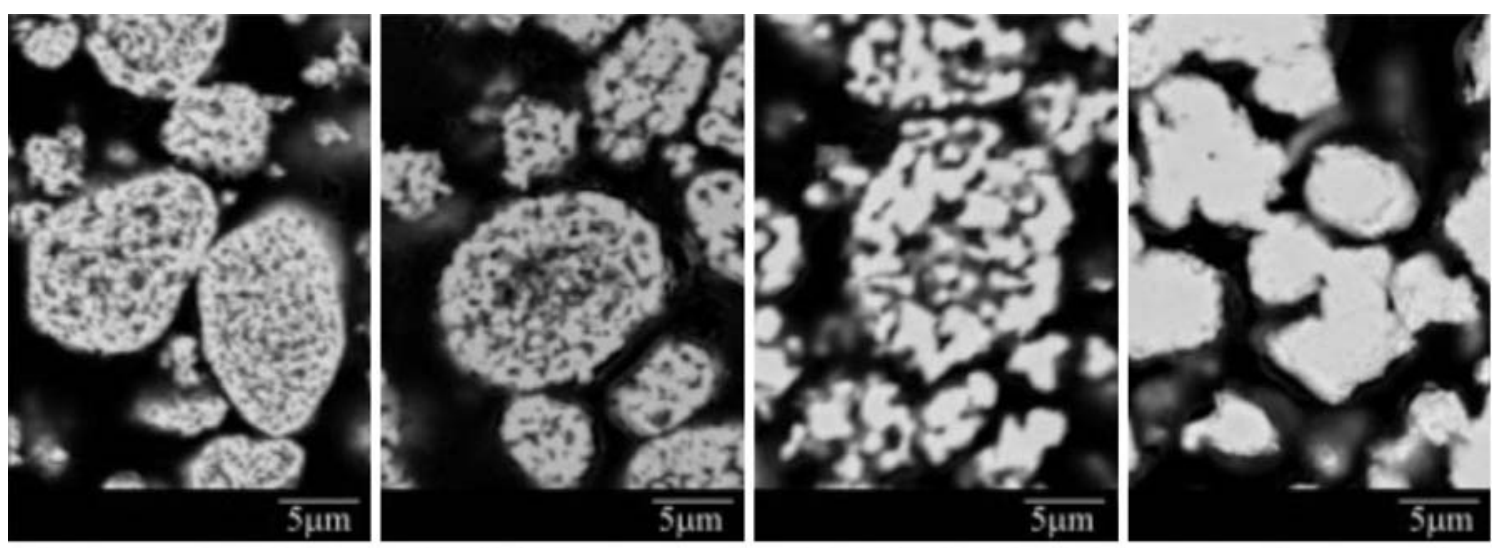

$60 \mathrm{~min}$
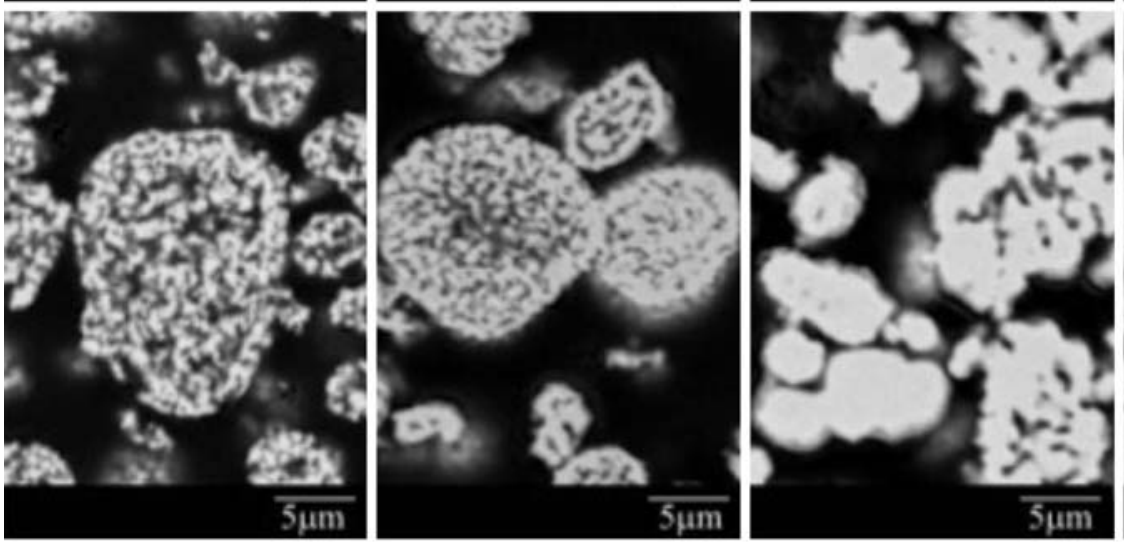

$600^{\circ} \mathrm{C}$

$700^{\circ} \mathrm{C}$

$800^{\circ} \mathrm{C}$

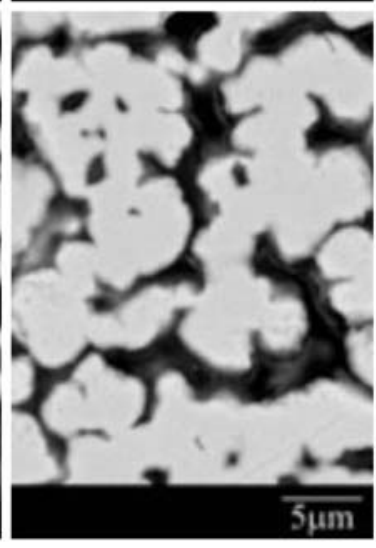

$120 \mathrm{~min}$

Fig. 9-SEM micrographs of the cross sections of $\mathrm{BNC}$ samples reduced in 15 pct $\mathrm{H}_{2}-\mathrm{N}_{2}$ at 60 and 120 min $\left(10{ }^{\circ} \mathrm{C} /\right.$ min heating rate) at various temperatures, showing extensive densification at temperatures above $700{ }^{\circ} \mathrm{C}$.

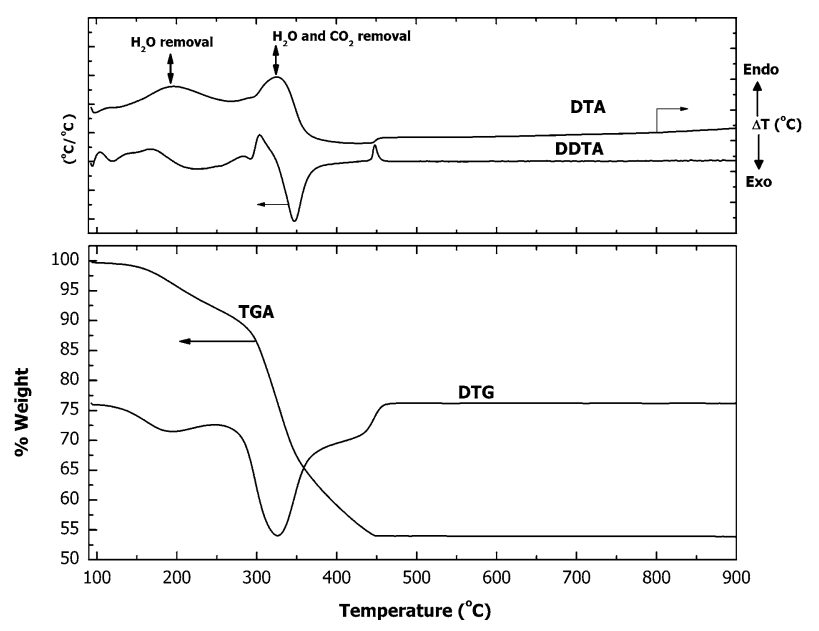

Fig. 10 - DTA, TGA, DTG, and DDTA curves of BNC samples reduced in 5 pct $\mathrm{H}_{2}-\mathrm{N}_{2}$ with a heating rate of $10{ }^{\circ} \mathrm{C} / \mathrm{min}$.

be suggested that the decomposition of $\mathrm{BNC}$ to $\mathrm{NiO}$ occurred from $80{ }^{\circ} \mathrm{C}$ to approximately $370{ }^{\circ} \mathrm{C}$, followed by $\mathrm{NiO}$ reduction to $\mathrm{Ni}$ occurring at approximately $450{ }^{\circ} \mathrm{C}$. Absence of thermal and weight changes recorded by DTA and TGA curves indicates that no reactions occurred at temperatures above $500{ }^{\circ} \mathrm{C}$; this is in agreement with microstructural and XRD analyses that indicate nearly complete reduction to $\mathrm{Ni}$ metal. The recrystallization and densification of $\mathrm{Ni}$ at temperatures higher than $700{ }^{\circ} \mathrm{C}$, as evident from SEM observations, are not detected in the DTA spectrum, which may be due to the associated energy changes being very small.

\section{Preoxidized BNC Sample Reduced in 15 Pct $\mathrm{H}_{2}-\mathrm{N}_{2}$ Gas Atmosphere}

During the BNC processing, for example, in a rotary kiln, the material moves from low-temperature oxidizing conditions at the feed input end to high-temperature reducing conditions at the discharge end. In order to simulate this, and to study the effect of preoxidation on the reduction behavior, BNC samples were first preoxidized in air, with a $10{ }^{\circ} \mathrm{C} / \mathrm{min}$ heating rate to $900{ }^{\circ} \mathrm{C}$, then reduced in a 15 pct $\mathrm{H}_{2}-\mathrm{N}_{2}$ gas atmosphere at various fixed temperatures for 30 minutes.

Figure 11 shows the XRD analyses of the preoxidized BNC samples reduced at different temperatures. At $110{ }^{\circ} \mathrm{C}$ to $200{ }^{\circ} \mathrm{C}$, the reduction was not started. Similarly to the directly reduced $\mathrm{BNC}$, nickel started to nucleate at the temperature range of $300{ }^{\circ} \mathrm{C}$ to $400{ }^{\circ} \mathrm{C}$. This is suggested from the XRD spectra at $340{ }^{\circ} \mathrm{C}$ and $400{ }^{\circ} \mathrm{C}$ showing $\mathrm{Ni}$ peaks. At $500{ }^{\circ} \mathrm{C}$ to $600{ }^{\circ} \mathrm{C}$, from the XRD result, it can be seen that the height of the highest $\mathrm{Ni}$ peak is comparable to the highest $\mathrm{NiO}$ peak. In contrast to the directly reduced $\mathrm{BNC}$, residual $\mathrm{NiO}$ was detected by XRD even at 


\begin{tabular}{|c|c|c|c|c|}
\hline $110^{\circ} \mathrm{C}$ & $\mathrm{NiO}$ & NiO & & $\stackrel{\mathrm{NiO}}{\Lambda}$ \\
\hline $200^{\circ} \mathrm{C}$ & Nio & $\mathrm{NiO}$ & & $\stackrel{\text { NiO }}{\Lambda}$ \\
\hline $300^{\circ} \mathrm{C}$ & Nio & ${ }^{\mathrm{NiO}} \underbrace{}_{\mathrm{Ni}}$ & $\mathbf{N i}$ & $\stackrel{\mathrm{NiO}}{\Lambda}$ \\
\hline $400^{\circ} \mathrm{C}$ & $\mathrm{NiO}_{\mathrm{H}}$ & ${ }^{\mathrm{NiO}} \mathrm{Ni}$ & $\underbrace{\mathbf{N i}}$ & NiO \\
\hline $500^{\circ} \mathrm{C}$ & $\mathrm{NiO}$ & ${ }^{\mathrm{NiO}} \mathrm{N}$ & $\mathbf{N i}$ & $\underbrace{\text { NiO }}$ \\
\hline $600^{\circ} \mathrm{C}$ & NiO & $\mathrm{NiO}^{\mathrm{N}}$ & $\overbrace{}^{\mathbf{N i}}$ & NiO \\
\hline $700^{\circ} \mathrm{C}$ & $\mathrm{NiO}$ & Nio ${ }^{\mathrm{N}}$ & $\stackrel{\mathbf{N i}}{\Lambda}$ & NiO \\
\hline $800^{\circ} \mathrm{C}$ & & $N$ & 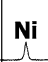 & \\
\hline $900^{\circ} \mathrm{C}$ & & $\mathbf{N}$ & $\mathfrak{N i}^{\mathbf{N i}}$ & \\
\hline
\end{tabular}

Fig. 11-XRD spectra of the preoxidized BNC samples in air at $900{ }^{\circ} \mathrm{C}\left(30 \mathrm{~min}, 10{ }^{\circ} \mathrm{C} / \mathrm{min}\right.$ heating rate), which were then reduced in 15 pct $\mathrm{H}_{2}-\mathrm{N}_{2}\left(30 \mathrm{~min}, 10^{\circ} \mathrm{C} / \mathrm{min}\right.$ heating rate) at various fixed temperatures; $\mathrm{Cu} K_{\alpha}$ radiation is used.

$700{ }^{\circ} \mathrm{C}$. At $900{ }^{\circ} \mathrm{C}$, no $\mathrm{NiO}$ XRD peaks were observed; however, microstructure observation revealed the presence of residual $\mathrm{NiO}$ (Figure 12).

The morphology and microstructure of the particles after heating in $15 \mathrm{pct} \mathrm{H}_{2}-\mathrm{N}_{2}$ between $110^{\circ} \mathrm{C}$ and $200{ }^{\circ} \mathrm{C}$ are similar to that of the starting preoxidized particles. The particles exhibited a structure that is composed of a random distribution of a very small $(<0.1 \mu \mathrm{m})$ recrystallized nickel-oxide grains, rather than a clearly defined layer structure.

Figures 12(a) and (b) show the morphology of the surface and microstructure of sectioned particles at $340{ }^{\circ} \mathrm{C}$. In this temperature range, the particles started to agglomerate as the nickel formed at the surface, provides bridges between particles. The size of the agglomerates can be more than $400 \mu \mathrm{m}$.

Between $500{ }^{\circ} \mathrm{C}$ to $600{ }^{\circ} \mathrm{C}$, surface pores were observed on the nickel particles; the size can be up to $1 \mu \mathrm{m}$ or more (Figure 12(c)). A concentric layer structure with distinct gaps between layers was observed in some of the particles (Figure 12(d)).

At $700{ }^{\circ} \mathrm{C}$, quite dramatic changes in the nickelproduct structure were initiated with the densification of the nickel metal on the surface of the particles, resulting in the formation of a dense, nickel layer on the particle surface (Figures 12(e) and (f)).

At $800{ }^{\circ} \mathrm{C}$ and $900{ }^{\circ} \mathrm{C}$, the particles were characterized by the presence of thick, dense, metallic-Ni layer that encapsulates the residual $\mathrm{NiO}$ inside the particles (Figures 12(g) and (h)). This dense nickel consists of recrystallized nickel with large-grain size, and the particles were sintered together. The thick, dense $\mathrm{Ni}$ made further reduction of the $\mathrm{NiO}$ by direct access of $\mathrm{H}_{2}$ gas impossible.

Figure 13 is an example of the DTA and TGA results of the reduction in 5 pct $\mathrm{H}_{2}-\mathrm{N}_{2}$ (heating rate of $10{ }^{\circ} \mathrm{C} / \mathrm{min}$ ) of preoxidized $\mathrm{BNC}$ in air at $900{ }^{\circ} \mathrm{C}$ for
30 minutes. The decrease in weight starting at $340{ }^{\circ} \mathrm{C}$, as can be seen from the TGA curve, suggests that $\mathrm{NiO}$ starts to reduce at approximately this temperature. This $\mathrm{NiO}$ reduction, however, continued up to $900{ }^{\circ} \mathrm{C}$. This is in contrast with the direct reduction of $\mathrm{BNC}$ in the same atmosphere where the transformation to $\mathrm{Ni}$ is completed at $450{ }^{\circ} \mathrm{C}$ (Figure 10).

\section{Transformation Sequence}

The experimental results have shown that the microstructural changes taking place in the processing of BNC depend critically on the thermal history. The key changes in the samples during the experiments, derived by interpretation of results of the various analyses described previously, are summarized in Table II. The changes in the specific surface area, measured using the BET method, during BNC processing are summarized in Table III. The results of the specific surface-area measurements support the interpretation of transformations derived from SEM and other analyses.

In an oxidizing condition, i.e., in air, BNC decomposition is believed to occur in two stages. The first stage involves the removal of physically absorbed water. The formation of $\mathrm{NiO}$ occurs at the second stage at a temperature between $300{ }^{\circ} \mathrm{C}$ to $400{ }^{\circ} \mathrm{C}$; this transformation occurs without significant change in the specific surface area, i.e., from $238 \mathrm{~m}^{2} / \mathrm{g}$ in the original BNC to $204 \mathrm{~m}^{2} / \mathrm{g}$ at $340{ }^{\circ} \mathrm{C}$ (Table III). At approximately $660{ }^{\circ} \mathrm{C}$, the recrystallization of $\mathrm{NiO}$ commences; as the temperature increases, sintering and grain growth of the recrystallized $\mathrm{NiO}$ grains take place within the original particles. By $700{ }^{\circ} \mathrm{C}$, these processes have resulted in a significant decrease of specific surface area to $6.6 \mathrm{~m}^{2} / \mathrm{g}$; at $900{ }^{\circ} \mathrm{C}$, fully recrystallized $\mathrm{NiO}$ particles are formed with specific surface area of $1.1 \mathrm{~m}^{2} / \mathrm{g}$.

Direct gaseous reduction of $\mathrm{BNC}$ is suggested to take place in three stages. The first stage is the removal of physically entrained water. In the second stage, BNC decomposes to nickel oxide, accompanied by the removal of chemically bound $\mathrm{H}_{2} \mathrm{O}$ and $\mathrm{CO}_{2}$, producing particles having a porous, concentric-ring structure. In the third stage, nickel oxide is reduced to nickel metal, accompanied by the removal of oxygen. All of these changes can occur at relatively low temperatures, i.e., below $500{ }^{\circ} \mathrm{C}$.

Similar to the case of calcination in air, at these low temperatures, the $\mathrm{NiO}$ particles produced from the decomposition of BNC are porous (Figure $8(\mathrm{~b})$ ); as a consequence, they still have a high, specific surface area, i.e., $207 \mathrm{~m}^{2} / \mathrm{g}$ at $340{ }^{\circ} \mathrm{C}$. This high, specific surface area facilitates the delivery of fresh reducing gas to the interior of the particles, thus promoting the complete reduction of the nickel oxide at low temperatures, provided it has a high, chemical rate of $\mathrm{NiO}$ reduction, i.e., a high partial pressure of hydrogen $\left(15\right.$ pct $\left.\mathrm{H}_{2}-\mathrm{N}_{2}\right)$. Further increases in temperature, i.e., above $500{ }^{\circ} \mathrm{C}$, result in the densification of the nickel product, accompanied by a significant decrease in specific surface area, i.e., the specific surface areas at $700{ }^{\circ} \mathrm{C}$ and $900{ }^{\circ} \mathrm{C}$ are 1.1 and $0.3 \mathrm{~m}^{2} / \mathrm{g}$, respectively. 

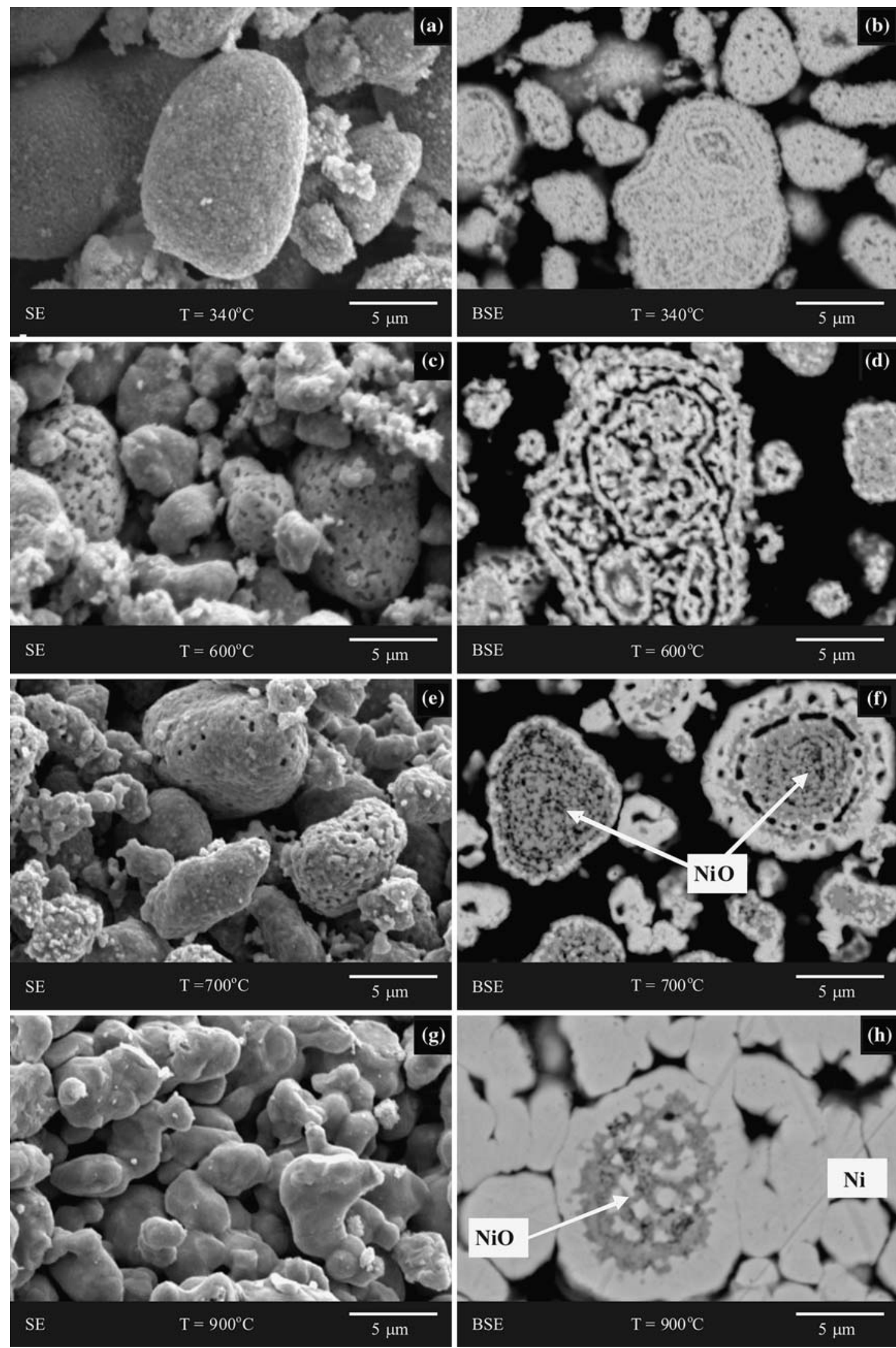

Fig. 12-SEM micrographs of the surface (left column) and the sections (right column) of the preoxidized (for $30 \mathrm{~min}$ at $900{ }^{\circ} \mathrm{C}, 10{ }^{\circ} \mathrm{C} / \mathrm{min}$ heating rate) $\mathrm{BNC}$ sample reduced in $15 \mathrm{pct} \mathrm{H}_{2}-\mathrm{N}_{2}\left(30 \mathrm{~min}, 10{ }^{\circ} \mathrm{C} / \mathrm{min}\right)$ at various temperatures: $(a)$ and $(b) 340{ }^{\circ} \mathrm{C},(c)$ and $(d) 600{ }^{\circ} \mathrm{C},(e)$ and $(f) 700{ }^{\circ} \mathrm{C}$, and $(g)$ and $(h) 900{ }^{\circ} \mathrm{C}$. ( $\mathrm{NiO}$ and $\mathrm{Ni}$ appear as dark gray and bright phases, respectively, in $(d)$, $(f)$, and $\left.(h)\right)$. 


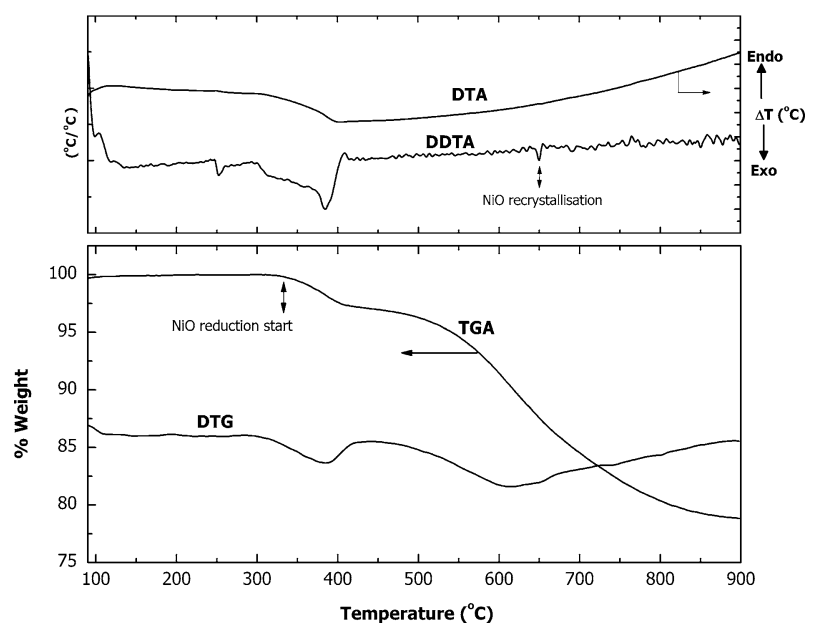

Fig. 13-Differential thermal analysis (DTA), thermal gravimetry analysis (TGA), first derivative of TGA (DTG), and first derivative of DTA (DDTA) curves of pre-oxidised BNC (at $900{ }^{\circ} \mathrm{C}, 30 \mathrm{~min}$, with heating rate $10{ }^{\circ} \mathrm{C} / \mathrm{min}$ ) samples reduced in $5 \% \mathrm{H}_{2}-\mathrm{N}_{2}$ with heating rate $10^{\circ} \mathrm{C} / \mathrm{min}$.

In the case of the preoxidized $\mathrm{BNC}$ (at $900{ }^{\circ} \mathrm{C}$ ) reduced in a 15 pet $\mathrm{H}_{2}-\mathrm{N}_{2}$ condition at $300{ }^{\circ} \mathrm{C}$ to $400{ }^{\circ} \mathrm{C}$, the nickel metal nucleates on the surface of the recrystallized $\mathrm{NiO}$ grains. The reduction, however, proceeds at a slower rate compared to the directly reduced BNC. This is believed to be mainly due to the larger grain size, denser sintered structure, and higher crystallinity (low reducibility) of the recrystallized nickel oxide particles as a result of preoxidation. This observation is supported by the BET-specific surface-area measurements. Table III shows that the specific surface area of the preoxidized samples at $900{ }^{\circ} \mathrm{C}$ is $1.1 \mathrm{~m}^{2} / \mathrm{g}$.

As the temperature is increased to $660{ }^{\circ} \mathrm{C}$, it appears that recrystallization of the unreduced $\mathrm{NiO}$ occurs, as could be suggested from the small peak in the DDTA curve in Figure 13. As the temperature reaches $700{ }^{\circ} \mathrm{C}$ to $800{ }^{\circ} \mathrm{C}$, recrystallization, grain growth, and sintering of the nickel-metal product take place. As a result, there is a closing of pores on the particles' surfaces. Under the process conditions with the materials used in the current study, the rate of nickel densification (closing up of the pores) on the particle surface progresses quickly, relative to the overall reduction, resulting in the formation of a dense, nickel-metal product layer before the full reduction of the nickel oxide is complete. Once this dense, nickel microstructure has formed, further reduction of this trapped nickel oxide becomes progressively more difficult. There is no direct contact between the reducing gas and the nickel oxide at this stage; further removal of oxygen can only take place by solid-state diffusion through the dense, nickel layer formed, i.e., the reaction becomes mass transfer limited. As further oxygen is removed in this way, the layer thickness of the dense nickel becomes progressively greater, and the diffusion flux of oxygen through the layer is progressively reduced. Prolonged heating times at high temperatures $\left(>800{ }^{\circ} \mathrm{C}\right)$ will also have a negative effect, as it promotes densification of overall agglomerated material. This is supported by the BET-specific, surface-area measurements; the specific surface area of the preoxidized (at $900{ }^{\circ} \mathrm{C}$ ) samples reduced at $700{ }^{\circ} \mathrm{C}$ and $900{ }^{\circ} \mathrm{C}$ are 0.52 and $0.44 \mathrm{~m}^{2} / \mathrm{g}$, respectively.

This analysis indicates that the strategy to approach a more complete reduction of nickel oxide to nickel metal is to control the relative rate of densification of nickel product to the overall $\mathrm{NiO}$ reduction rate. To demonstrate this point, additional sets of experiments were carried out.

Initial tests were conducted by first oxidizing $\mathrm{BNC}$ at $500{ }^{\circ} \mathrm{C}$ for 30 minutes prior to subsequent isothermal reductions at $500{ }^{\circ} \mathrm{C}$ to $900{ }^{\circ} \mathrm{C}$ in 15 pct $\mathrm{H}_{2}-\mathrm{N}_{2}$ for 30 minutes. The temperature of $500{ }^{\circ} \mathrm{C}$ was chosen as the preoxidation temperature for the following reasons:

(1) at this temperature, the nickel oxide formed has lower crystallinity, higher porosity, and a higher surface/volume ratio, as compared to $\mathrm{NiO}$ preoxidized at $900{ }^{\circ} \mathrm{C}$ (Figure 4); and

(2) $500{ }^{\circ} \mathrm{C}$ is well below the $\mathrm{Ni}$ and $\mathrm{NiO}$ recrystallization temperatures of $600{ }^{\circ} \mathrm{C}$ to $700{ }^{\circ} \mathrm{C}$ (Table II) and below the temperature of $700{ }^{\circ} \mathrm{C}$, at which the sintering and the densification of the porous nickel product is first observed (Table II).

The selected microstructures of BNC samples preoxidized at $500{ }^{\circ} \mathrm{C}$, and subsequently reduced at $500{ }^{\circ} \mathrm{C}$ to $900{ }^{\circ} \mathrm{C}$, are shown in Figures 14(a) through (d). From the microstructures, it can be seen that even at $500{ }^{\circ} \mathrm{C}$, the nickel oxide has completely reduced to nickel metal. This result is in sharp contrast with samples preoxidized at $900{ }^{\circ} \mathrm{C}$, then reduced at the same temperatures (Figure 12) for 30 minutes, in which $\mathrm{NiO}$ is trapped inside layers of dense, nickel metal. This demonstrates that controlling the nickel-oxide structure prior to reduction process, i.e., increasing its reducibility, can result in a complete reduction of BNC to nickel. The key changes observed in the samples from this set of experiments are also summarized in Table II.

The second series of tests conducted was direct reduction of $\mathrm{BNC}$ in $1.5 \mathrm{pct} \mathrm{H}_{2}-\mathrm{N}_{2}$ at temperatures between $600{ }^{\circ} \mathrm{C}$ and $900{ }^{\circ} \mathrm{C}$. Figure 15 shows selected SEM micrographs from these tests. It can be seen that at $700{ }^{\circ} \mathrm{C}$, residual $\mathrm{NiO}$ trapped inside dense nickel was observed. This is not observed in the case of reduction in 15 pet $\mathrm{H}_{2}-\mathrm{N}_{2}$ at the same temperature. By decreasing the partial pressure of hydrogen by an order of magnitude, the chemical rate of reduction of nickel oxide is decreased; the densification of nickel product occurs before the reduction of nickel oxide is complete, which results in the formation of trapped residual nickel oxide. As the temperature is increased, more densification and agglomeration of the nickel occurs, which means further removal of the trapped $\mathrm{NiO}$ is more difficult. At $800{ }^{\circ} \mathrm{C}$ and at $900{ }^{\circ} \mathrm{C}$, residual $\mathrm{NiO}$ enclosed in a dense $\mathrm{Ni}$ network, forming denser agglomerates, is observed (Figures 15(c) and (d)).

Previous studies of the reduction of $\mathrm{NiO}$ with hydrogen gas ${ }^{[10-16]}$ have shown that reduction to metallic nickel occurs readily with the formation of porous, nickel metal product. The porous product allows continuous access by gas-phase diffusion from the bulk gas to the $\mathrm{NiO}$ interface, at which a chemical reaction 


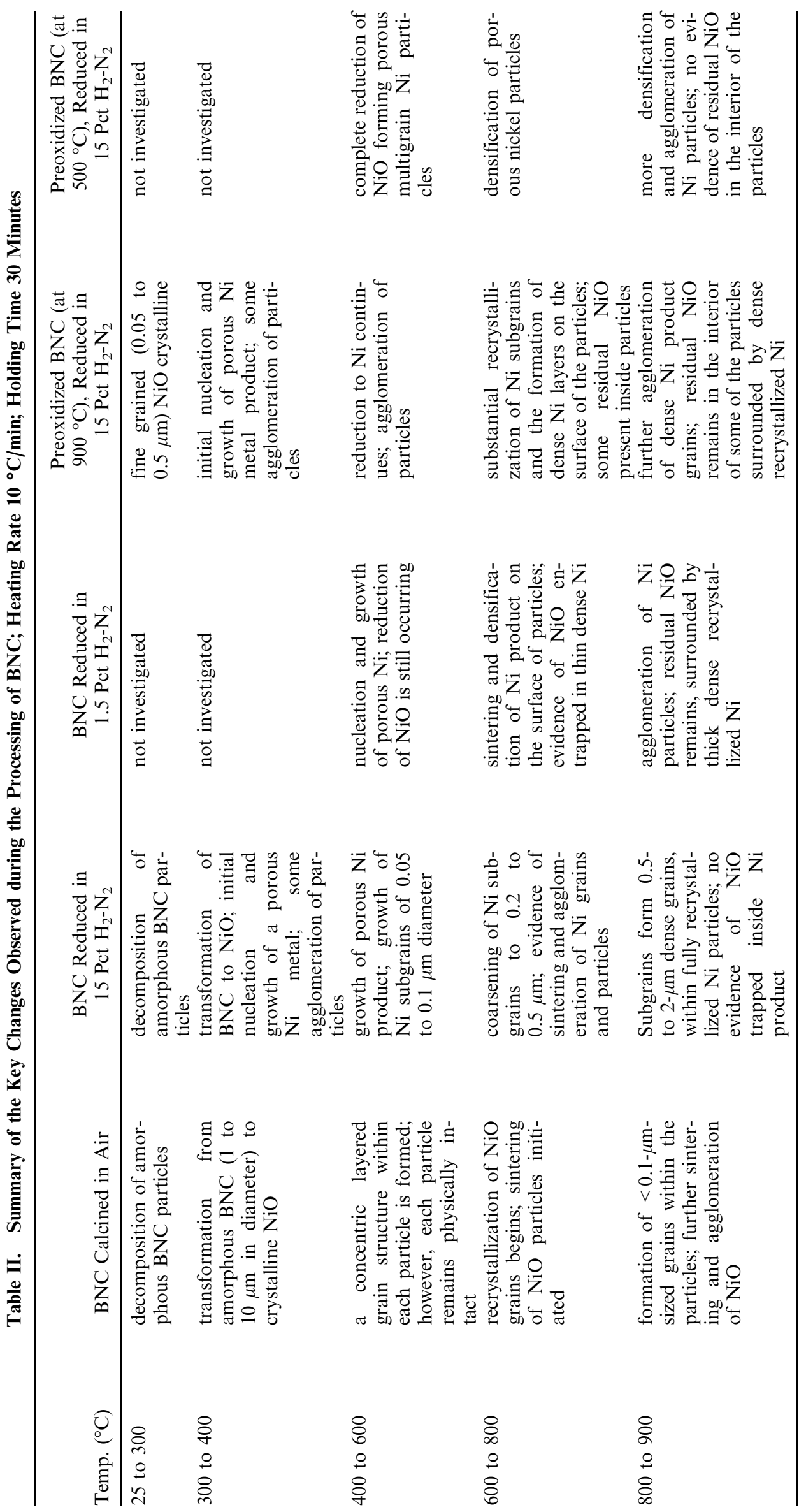


Table III. Summary of the Measured BET Specific Surface Areas from the Processing of BNC (Heating Rate $10{ }^{\circ} \mathrm{C} / \mathrm{min}$; Holding Time 30 Minutes)

\begin{tabular}{lccc}
\hline & \multicolumn{3}{c}{ BET Specific Surface Area $\left(\mathrm{m}^{2} / \mathrm{g}\right)$} \\
\cline { 2 - 4 } & $\begin{array}{c}\text { BNC } \\
\text { Temperature }\end{array}$ & $\begin{array}{c}\text { BNC Reduced } \\
\text { Calcined } \\
\text { in Air }\end{array}$ & $\begin{array}{c}\text { Preoxidized BNC } \\
\left.\text { (at } 900{ }^{\circ} \mathrm{C}\right),\end{array}$ \\
$\left.{ }^{\circ} \mathrm{C}\right)$ & $\mathrm{H}_{2}-\mathrm{N}_{2}$ & $\begin{array}{c}\text { Reduced in } \\
15 \mathrm{Pct}_{2}-\mathrm{N}_{2}\end{array}$ \\
\hline 25 (initial) & 238 & 238 & 1.1 \\
340 & 204 & 207 & 1.5 \\
700 & 6.6 & 1.2 & 0.5 \\
900 & 1.1 & 0.3 & 0.4 \\
\hline
\end{tabular}

between gas and oxide occurs. The resultant $\mathrm{H}_{2} \mathrm{O}$ product gas is also able to diffuse through the porous product, thus enabling the reduction reaction to proceed to completion. It has been shown in the present study that under certain conditions, the morphology of the $\mathrm{Ni}$ metal product microstructure can change, leading to the change in the rate-limiting reaction mechanism. The formation of a dense, product layer leads to a significant reduction in the overall rate of oxygen removal from the sample.

Utigard et al. ${ }^{[20]}$ reported that in temperature range of $700{ }^{\circ} \mathrm{C}$ to $900{ }^{\circ} \mathrm{C}$, there is a decrease in the $\mathrm{NiO}$ reduction rates. Based on their extended experiments, they suggested that this is not due to physical changes of the oxide, nor the metallic phases. They speculated that the slowdown in the rate might be due to grain growth of the nickel formed or by surface segregation of sulfur. It should be noted that the characteristics, such as particle size, purity, etc., of the $\mathrm{NiO}$ and experimental technique used in their study are different than that used in the current study.

The current study shows that in the temperature range of $700{ }^{\circ} \mathrm{C}$ to $900{ }^{\circ} \mathrm{C}$, there are several fundamental phenomena occurring simultaneously that may be responsible for the lowering of the $\mathrm{NiO}$ reduction kinetics. These include the $\mathrm{NiO}$ recrystallization and grain growth $\left(600{ }^{\circ} \mathrm{C}\right.$ to $\left.900{ }^{\circ} \mathrm{C}\right) ; \quad \mathrm{NiO}$ sintering $\left(>800^{\circ} \mathrm{C}\right)$; $\mathrm{Ni}$ product recrystallization and grain growth $\left(>700^{\circ} \mathrm{C}\right) ; \quad \mathrm{Ni}$ product densification $\left(>700{ }^{\circ} \mathrm{C}\right)$; and agglomeration of particles $\left(>700{ }^{\circ} \mathrm{C}\right)$. It is also shown in the present study that the thermal history and original microstructure of the material have
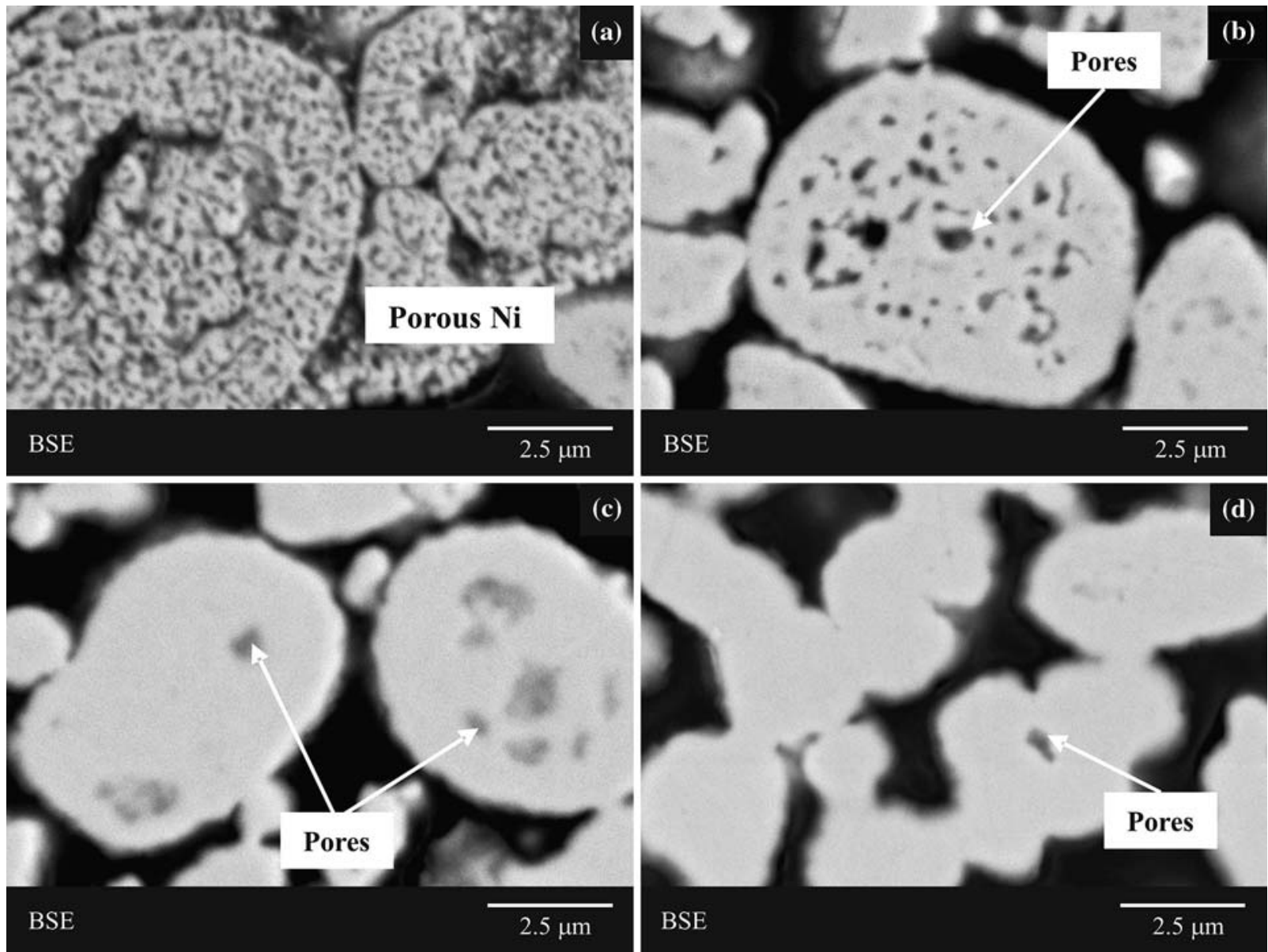

Fig. 14 - SEM micrographs of the sections of the preoxidized (at $500{ }^{\circ} \mathrm{C}$ for 30 min) BNC sample reduced in 15 pct $\mathrm{H}_{2}-\mathrm{N}_{2}$ for 30 min at various temperatures: (a) $500{ }^{\circ} \mathrm{C},(b) 700{ }^{\circ} \mathrm{C},(c) 800^{\circ} \mathrm{C}$, and $(d) 900{ }^{\circ} \mathrm{C}$. The gray regions inside the particles are pores in the nickel product, not residual nickel oxide. 

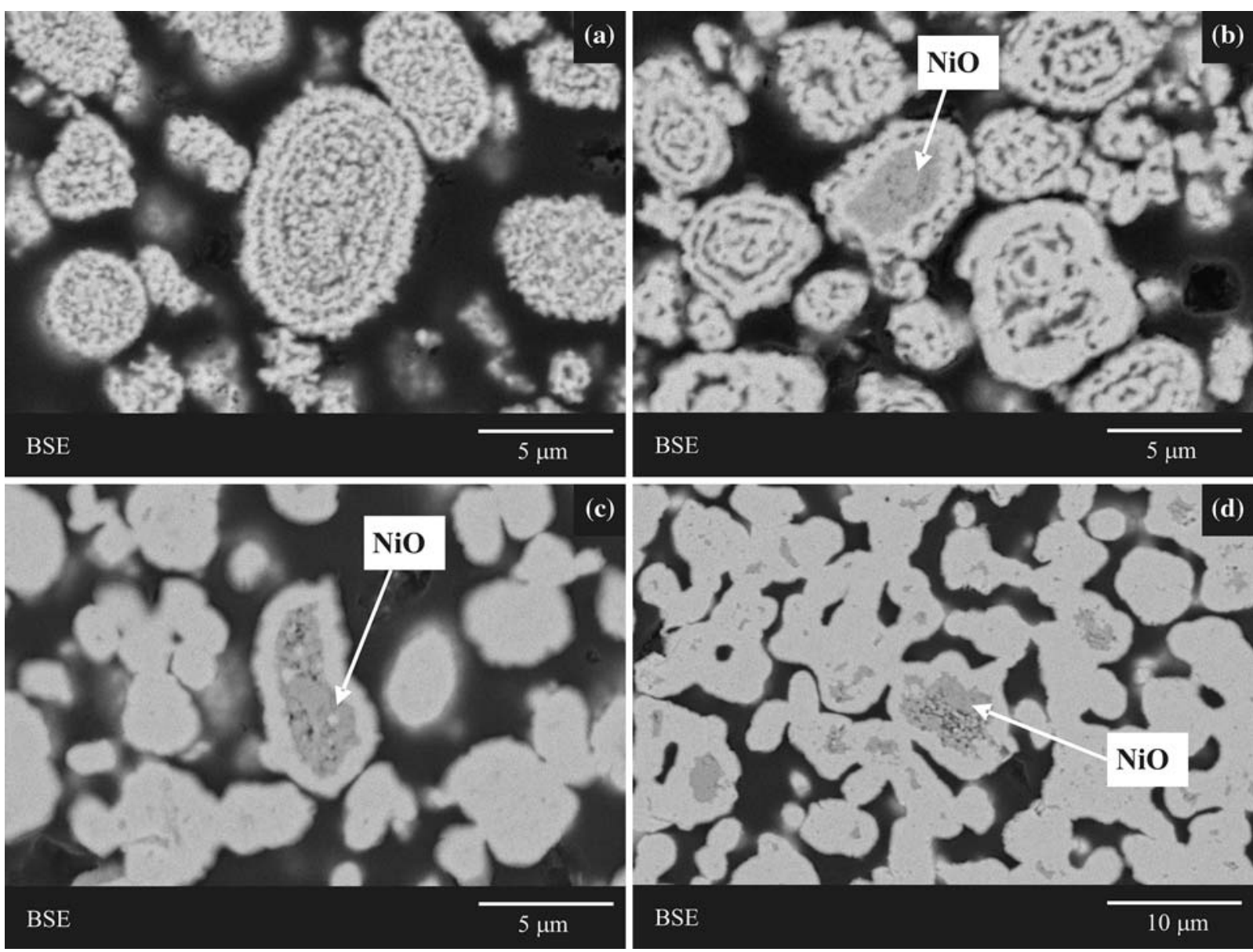

Fig. 15-Backscattered electron images showing internal microstructures of $\mathrm{BNC}$ reduced in 1.5 pct $\mathrm{H}_{2}-\mathrm{N}_{2}$; heating rate $10{ }^{\circ} \mathrm{C} /$ min at various temperatures: (a) $600{ }^{\circ} \mathrm{C},(b) 700{ }^{\circ} \mathrm{C},(c) 800{ }^{\circ} \mathrm{C}$, and $(d) 900{ }^{\circ} \mathrm{C}$. The gray phases are the residual nickel oxide.

a significant effect on the microstructure evolution, and hence, on the final microstructure of the nickel product.

\section{SUMMARY}

A systematic investigation of changes in the phases present, the product surface, and the internal microstructures in basic nickel carbonate during controlled oxidation and reduction conditions at temperatures between $110{ }^{\circ} \mathrm{C}$ and $900{ }^{\circ} \mathrm{C}$ has been carried out. The results show that the thermal history and original microstructure of the material have significant effects on the microstructure evolution and, hence, on the final microstructure of the nickel product. The fundamental phenomena that are observed to contribute to the change of the physical and chemical characteristics of the particles during the process, affecting the final microstructure, are as follows:

1. chemical changes, i.e., decomposition, reduction reactions, and oxidation reactions;

2. $\mathrm{NiO}$ and $\mathrm{Ni}$ recrystallization and grain growth; and 3. $\mathrm{NiO}$ and $\mathrm{Ni}$ sintering and densification.

The findings of the present study have clear implications for industrial practice, demonstrating that the key to achieving complete reduction of $\mathrm{NiO}$ by hydrogen gas is by controlling the relative rates of densification of nickel product and the overall reduction rate of nickel oxide. High extent of $\mathrm{NiO}$ reduction is favored by the following steps:

1. maintaining a high-NiO, specific surface area to avoid $\mathrm{NiO}$ and $\mathrm{Ni}$ recrystallization and densification, which is achieved by carrying out reduction below $600{ }^{\circ} \mathrm{C}$; and

2. maintaining a high chemical rate, which is favored by high $\mathrm{H}_{2}$ partial pressures and high $\mathrm{H}_{2} / \mathrm{H}_{2} \mathrm{O}$ ratios (i.e., high chemical driving force for reduction).

\section{ACKNOWLEDGMENTS}

The authors thank the BHP Billiton Yabulu Refinery for supplying the basic nickel carbonate samples. The authors also acknowledge the financial support from the Australian Research Council and the BHP Billiton Yabulu Refinery as part of an ARC Linkage project. The authors further thank Mr. John Fittock and Dr. Joy Morgan (Yabulu Refinery) for valuable discussions. MAR also thanks Mr. Jiang Chen for carrying out the TGA/DTA measurements. 


\section{REFERENCES}

1. H. Schmalzried: Solid State Reactions, transl. A.D. Pelton, Academic Press, New York, NY, 1974, pp. 166-70.

2. P. Delmon: in Reactivity of Solids, J.S. Anderson, ed., Chapman and Hall, London, 1972, pp. 567-75.

3. N.B. Hannay: Treatise on Solid State Chemistry, vol. 4, Reactivity of Solids, Plenum Press, New York, NY, 1976, pp. 193-280.

4. V.V. Boldyrev: Reactivity of Solids: Past, Present, and Future, IUPAC, Blackwell Science, Cambridge, United Kingdom, 1996.

5. J. Szekely, J.W. Evans, and H.Y. Sohn: Gas-Solid Reactions, Academic Press, New York, NY, 1976.

6. D.A. Young: Decomposition of Solids, The International Encyclopaedia of Physical Chemistry and Chemical Physics, Topic 21, Vol. 1, Pergamon Press, Oxford, United Kingdom, 1966, pp. 1, 38, 65, and 105.

7. J.H. Canterford: Miner. Sci. Eng., 1975, vol. 7 (1), pp. 3-17.

8. L.L. Bergeson: EU's New Chemical Policy will hurt U.S. Competitiveness, Chem. Process. Mag., Oct. 9, 2003, http://www. chemicalprocessing.com/articles/2003/143.html?page $=$ print $\quad($ accessed September 19, 2007).

9. MSDS (Material Safety Data Sheet) Information, http://www.haz safety.pf.uq.edu.au/chemwatch/ (accessed September 19, 2007).

10. R.M. Mallya and A.R.V. Murthy: J. Ind. Inst. Sci., 1961, vol. 43 (3), pp. 131-40 and 141-47.

11. W.M. Shaheen: Mater. Lett., 2002, vol. 52, pp. 272-82.
12. H. Henmi, M. Mori, T. Hirayama, N. Mizutani, and M. Kato: Thermochim. Acta, 1986, vol. 104, pp. 101-09.

13. M. Hirai and H. Yamamoto: J. Mass Spectrom. Soc. Jpn., 1998, vol. 46 (4), pp. 296-98.

14. S.A.A. Mansour: Thermochim. Acta, 1993, vol. 228, pp. 155-71.

15. F. Benton and P.H. Emmett: J. Am. Ceram. Soc., 1924, vol. 46 (12), pp. 2728-37.

16. W. Pluschkell and B.V.C. Sarma: Arch. Eisenhuttenwes., 1974, vol. 45 (1), pp. 23-31.

17. Y.K. Rao and A.H. Rashed: Trans. Inst. Min. Metall, Sect. C, 2001, vol. 110, pp. 1-6.

18. A.H. Rashed and Y.K. Rao: Chem. Eng. Commun., 1996, vol. 156, pp. $1-30$.

19. Y. Iida and K. Shimada: Bull. Chem. Soc. Jpn., 1960, vol. 33 (9), pp. 1194-96.

20. T.A. Utigard, M. Wu, G. Plascencia, and T. Marin: Chem. Eng. Sci., 2005, vol. 60, pp. 2061-68.

21. T.A. Utigard, G. Plascencia, T. Marin, A.E.M. Warner, J. Liu, A. Vahed, and M. Muinonen: Can. Metall. Q., 2005, vol. 44 (3), pp. 421-28.

22. J.G. Reid and J.E. Fittock: Proc. Int. Laterite Nickel Symp. 2004, Mar. 2004, TMS, Warrendale, PA, pp. 599-618.

23. B.D. Cullity and S.R. Stock: Elements of X-ray Diffraction, Prentice-Hall International, Upper Saddle River, NJ, 2001, p. 170. 